\title{
Organic matter budget in the Southeast Atlantic continental margin close to the Congo Canyon: In situ measurements of sediment oxygen consumption
}

\author{
C. Rabouille ${ }^{a,}{ }^{*}$, J.-C. Caprais ${ }^{b}$, B. Lansard ${ }^{a}$, P. Crassous $^{b}$, K. Dedieu ${ }^{a}$, J.L. Reyss $^{a}$ and A. \\ Khripounoff $^{b}$
}

\author{
a Laboratoire des Sciences du Climat et de l'Environnement, UMR CEA-CNRS-UVSQ et IPSL, domaine du \\ CNRS, av. de la Terrasse, 91198 Gif sur Yvette, France \\ ${ }^{\mathrm{b}}$ IFREMER, Département DEEP/LEP, Centre de Brest, BP70, 29280 Plouzané, France
}

*: Corresponding author : C. Rabouille, email address : christophe.rabouille@Isce.ipsl.fr

\begin{abstract}
:
A study of organic carbon mineralization from the Congo continental shelf to the abyssal plain through the Congo submarine channel and Angola Margin was undertaken using in situ measurements of sediment oxygen demand as a tracer of benthic carbon recycling. Two measurement techniques were coupled on a single autonomous platform: in situ benthic chambers and microelectrodes, which provided total and diffusive oxygen uptake as well as oxygen microdistributions in porewaters. In addition, sediment trap fluxes, sediment composition (Org-C, Tot- $\mathrm{N}, \mathrm{CaCO}$, porosity) and radionuclide profiles provided measurements of, respectively input fluxes and burial rate of organic and inorganic compounds.

The in situ results show that the oxygen consumption on this margin close to the Congo River is high with values of total oxygen uptake (TOU) of $4 \pm 0.6,3.6 \pm 0.5 \mathrm{mmol} \mathrm{m}-2 \mathrm{~d}-1$ at 1300 and $3100 \mathrm{~m}$ depth, respectively, and between $1.9 \pm 0.3$ and $2.4 \pm 0.2 \mathrm{mmol} \mathrm{m}-2 \mathrm{~d}-1$ at $4000 \mathrm{~m}$ depth. Diffusive oxygen uptakes (DOU) were $2.8 \pm 1.1,2.3 \pm 0.8,0.8 \pm 0.3$ and $1.2 \pm 0.1 \mathrm{mmol} \mathrm{m}-2 \mathrm{~d}-1$, respectively at the same depths. The magnitude of the oxygen demands on the slope is correlated with water depth but is not correlated with the proximity of the submarine channel-levee system, which indicates that cross-slope transport processes are active over the entire margin. Comparison of the vertical flux of organic carbon with its mineralization and burial reveal that this lateral input is very important since the sum of recycling and burial in the sediments is 5-8 times larger than the vertical flux recorded in traps.

Transfer of material from the Congo River occurs through turbidity currents channelled in the Congo valley, which are subsequently deposited in the Lobe zone in the Congo fan below $4800 \mathrm{~m}$. Ship board measurements of oxygen profiles indicate large mineralization rates of organic carbon in this zone, which agrees with the high organic carbon content (3\%) and the large sedimentation rate (19 $\mathrm{mm} y-1$ ) found on this site. The Lobe region could receive as high as $19 \mathrm{~mol} C \mathrm{~m}-2 \mathrm{y}-1,1 / 3$ being mineralized and $2 / 3$ being buried and could constitute the largest depocenter of organic carbon in the South Atlantic.
\end{abstract}

Keywords: In situ oxygen demand; Organic carbon recycling in sediments; Congo Submarine Canyon; Organic carbon burial; Sediment carbon budget 


\section{Introduction}

The transfer of carbon from land to sea has been recognized as an important pathway in the global carbon cycle (Degens et al., 1991; Spitzy and Ittekot, 1991; Schlünz and Schneider, 2000). Along the continent-ocean continuum, rivers play a major role and transport most of the $\sim 500 \mathrm{Tg} \mathrm{y}^{-1}$ of organic carbon carried from land to the global ocean (Spitzy and Ittekkot, 1991). The coastal ocean plays a key role in the continent-ocean transfer by mediating the carbon and nutrient brought by the rivers, promoting large primary production and allowing the mixing of terrestrial and marine organic carbon. (Dagg et al., 2004; McKee et al., 2004). One critical term in the ocean carbon budget is the particulate export flux from the coastal to the open ocean (Walsh, 1988; Wollast, 1993, 1998; Ver et al., 1999; Rabouille et al., 2001a; Andersson and Mackenzie, 2004). Large multidisciplinary science programmes have addressed this question on different margin types (SEEP; Biscaye and Anderson, 1994), OMEX (McCave et al., 2001; Wollast and Chou, 2001), MASFLEX, (Tsunogai et al., 2003) and have shown the diversity of the modes of transfer (i) in nature with terrestrial versus marine carbon (Goni et al., 1997; Hedges et al., 1997), dissolved versus particulate carbon transfer, (ii) in space with canyons playing a major role in channelling the particulate flux in some places, (iii) in time with storms, instabilities, current surge playing a significant role in transporting particles and carbon from the shelf to the slope and open ocean.

The Congo-Angola margin is unique to study the processes of carbon exchange through the margin. Indeed, near the river mouth, the transfers are dominated by the Congo River input which is the second largest river in the world by its water discharge (Milliman, 1991), but also displays one of the largest submarine channel that is connected to the river bed through the continental shelf (Babonneau et al., 2002a). This allows a peculiar mode of transfer with canyon and channel processes being effective in the transfer of river and shelf particles to the slope and open ocean. Yet, the budget of carbon transfer by the submarine channel and the lateral extension of the Congo channel influence over the Congo-Angola slope and rise are still poorly documented.

For this reason, we investigated the deposition, remineralization and burial of particulate organic carbon in the Congo-Angola continental margin sediments (from the shelf to the abyssal plain) in the region of the Congo channel. We used in situ and on board measurement systems coupling benthic chamber and oxygen microprofiler in order to estimate carbon recycling. We also performed long term sediment trap measurements to estimate vertical particle input, and short-live radionuclide profiles with sediment content of organic matter to calculate organic carbon burial. We compare deposition/mineralization/burial near the Congo channel and in locations $200 \mathrm{~km}$ south in order to assess the influence of the channel transfer on carbon fluxes on this margin. Using data from the canyon head and deep-sea fan, we investigate more directly the transport mechanisms and associated fluxes.

\section{Materials and methods}

\subsection{Background}

The mean annual discharge of the Congo River is $42,800 \mathrm{~m}^{3} \mathrm{~s}^{-1}$ (Kinga-Mouzeo, 1986) and it ranks second in the world by the water discharge after the Amazon River $\left(200,000 \mathrm{~m}^{3} \mathrm{~s}^{-1}\right)$. However, the annual suspended discharge is low in comparison with the Amazon River: the Congo sediment discharge is estimated to be $55 \times 10^{6}$ ton $\mathrm{y}^{-1}$ (Wetzel, 1993), whereas the Amazon sediment discharge is 17 times greater. This relatively low value is essentially the result of the low average elevation of the downstream watershed and trapping of most of the alluvial deposits in lakes (Bongo-Passi, 1984; Seylers et al., 2005). However the discharge of terrestrial materials can be significant during floods.

The Congo Submarine Canyon and Channel is described in Vangriesheim et al. (2009). Briefly, The Congo canyon and channel-levee system connect the estuary and the abyssal 
plain (>5100m) and extends over $760 \mathrm{~km}$ offshore, covering an estimated area of 300,000 $\mathrm{km}^{2}$ (Babonneau et al., 2002b). The present connection between the river and the abyssal plain via the channel is one of the original characteristics of the Congo system and explains the size of the deep sea fan which is one of the largest in the world still affected by turbidity sedimentation (Savoye et al., 2000).

The present day activity of the Congo deep-sea fan was documented by cable breaks near the canyon between 500 and $2300 \mathrm{~m}$ (Heezen et al., 1964), which were attributed to turbidities initiated by river floods. Recently, the occurrence of one episodic feature observed in 2001 (Khripounoff et al., 2003) shows the link between turbidity currents and enriched particulate material transport from the channel.

\subsection{Station locations}

To understand organic material cycling in superficial sediments of the Congo-Angola margin in relation with the presence of the Congo channel, a set of stations was investigated in 2001 (Biozaire 2) and in December 2003 and January 2004 (Biozaire 3, thereafter labelled 2003). Four stations were located along the channel from $330 \mathrm{~m}$ to $4800 \mathrm{~m}$ (Fig.1). All these stations were on the border (levee) of the channel except for the deepest station (Lobe), which was positioned into the channel. These stations were located in areas potentially affected by the turbidite activities. Two others south-westward stations located respectively on the top $(1300 \mathrm{~m})$ and at the bottom of the margin $(4000 \mathrm{~m})$ were chosen, as references, far from the channel (more than $200 \mathrm{~km}$ ). The main characteristics of the stations are summarized in Table 1.

Complete description of the hydrodymic condition in the Golf of Guinea is proposed in Vangriesheim et al. (2005, 2009). Briefly, the residual current was towards the south-east at $A, R$ and $C$. and towards the north-east at $D$. The mean velocity of the current was $7.3 \mathrm{~cm} \mathrm{~s}^{-1}$ at $A$ and always low (1.9 to $4.1 \mathrm{cms}^{-1}$ ) at the other stations. No relationship was observed between the current intensity and the particle flux.

\subsection{In situ measurements of oxygen fluxes and distribution: the RAP-Profilo structure}

The RAP 2 platform was used as a deep-sea lander to link two different types of in situ devices: a benthic chamber incubation system and an oxygen microprofiler (Fig. 2). This is the first report of combined deployment of these two equipments at the same time and at a distance less than $1 \mathrm{~m}$ apart.

\subsubsection{Benthic chamber-RAP2}

The principle of the benthic chambers of the RAP 2 (for a detailed description of the lander see Khripounoff et al., 2006) is to isolate and incubate a known volume of seawater in close contact with a predetermined sediment surface area. It is an autonomous lander equipped with three cylindric benthic chambers (30 $\mathrm{cm}$ in diameter). Three sampling cells, positioned within the chambers, enable water subsample collection $(100 \mathrm{~mL})$ at pre-determined intervals for later calculation of fluxes. The cells of the RAP2 were constructed with internal glass lining in order to prevent oxygen exchange with the outer sea water. The upper and lower plates that seal the cells are made of PVDF (polyvinylidene fluoride) plastic which proved to be the type of plastic, least permeable to oxygen. The position of the cells inside the chamber and their closure mechanism preclude any suction of water into the chamber. Each chamber also was equipped with $\mathrm{O}_{2}$ optode probes that continuously recorded the $\mathrm{O}_{2}$ concentration in the chamber water. Immediately after lander recovery, the sampling cells are removed from the chambers. The water samples are then collected by gravity flow directly in various vials.

Two methods were used to measure $\mathrm{O}_{2}$ consumption under the chambers of the respirometer: Dissolved oxygen concentration was analyzed in 10-mL water samples using the modified Winkler titration method (Carritt and Carpenter, 1966), which is the reference 
method performed in the laboratory. On duplicate aliquots, the end point is detected by potentiometry with combined platinum electrodes (Metrohm 6-048-100). The standard error of the measurements is $2 \mu \mathrm{mol} \mathrm{L} \mathrm{L}^{-1}$. To obtain in situ data with a better temporal resolution, the electrochemical sensor optode (Aanderaa) was used under each chamber. The principal attributes of this probe are its accuracy and long-term stability; its absence of stirring sensitivity (no oxygen consumption) and its low and predictable pressure response (Tengberg et al., 2006).

Total oxygen fluxes (TOU) were estimated from linear regression of the concentration versus time curve in the benthic chambers. The sediment oxygen consumption was calculated at each station from the results of chemical analysis of water samples (Winkler titration) and from the optode probe records. The oxygen exchange rate was obtained from the slope of the linear regression fitted to data points recorded while the $\mathrm{O}_{2}$ concentration was $>85 \%$ of the in situ value. An average flux was then calculated for each deployment from the different techniques and the three chambers using incubation times and chamber water volumes.

\subsubsection{Profilo-oxygen and resistivity microprofiles}

A microprofiler manufactured by Unisense ${ }^{\circledR}$ was integrated into the RAP 2 platform and used simultaneously with the benthic chambers. A complete description is given in Rabouille et al. (2003) and Dedieu et al. (2007). It consists of an autonomous micromanipulator that is coupled to microsensors of oxygen and $\mathrm{pH}$. These are lowered stepwise in the sediment and record the porewater oxygen concentration and $\mathrm{pH}$. Dissolved oxygen concentration were measured by Clark-type oxygen microelectrodes provided with a built-in reference and an internal guard cathode (Revsbech, 1989). The $\mathrm{O}_{2}$ microsensor had a tip outer diameter of $100 \mu \mathrm{m}$, a stirring sensitivity of $<1 \%$, a $90 \%$ response time $<10 \mathrm{~s}$ and a current drift less than $2 \%$ per hour. The electrode signals were recorded in the overlying water both before and after the profile to assess the stability of measurements. A threshold of $10 \%$ for this variation was used and profiles displaying larger variations were not considered in this study. Linear calibration of microelectrodes was achieved between bottom water oxygenation estimated by Winkler titration and the anoxic zone of the sediment. The vertical resolution of measurements was variable from 100 or $200 \mu \mathrm{m}$ near the sediment-water interface to 500 $\mu \mathrm{m}$ deeper in the sediment. The position of the sediment-water interface (SWI) relative to the in-situ oxygen profiles was determined using a modified version of the technique of Sweerts and De Beer (1989) which defined the SWI as the first point in the oxygen gradient, after the initial linear oxygen decrease in the DBL, with a slope increase of more than $20 \%$.

The diffusive oxygen uptake (DOU) was calculated using two different methods:

1) from the oxygen gradient obtained with the in situ profiler and the core profile by applying a simple1-dimensional Fick's first law of diffusion approach: $D O U=D_{0}(d C / d z)$, where DOU (mmolO2 m-2 d-1) is the diffusive oxygen uptake at the sediment-water interface, D0 $(\mathrm{cm} 2 \mathrm{~s}-1)$ is the $\mathrm{O} 2$ diffusion coefficient in sea-water at in situ temperature, $\mathrm{C}(\mu \mathrm{mol} \mathrm{I}-1)$ is the $\mathrm{O}_{2}$ concentration and $z(\mathrm{~cm})$ is the depth in the sediment.

2) by using the Profile software (Berg et al., 1998). This software consists of a 1D diffusionreaction model that recalculates oxygen consumption by matching profile curvature over depth slices. It has the advantage of accounting for the entire profile and being more robust than a single evaluation using Fick's first law. In our set of measurements, these two methods agree within $10-20 \%$.

Resistivity measurements were made with an electrode similar to that described by Andrews and Bennet (1981). The probe consisted of a narrow strip of epoxy (45 x $15 \times 5 \mathrm{~mm})$ in which four thin parallel wires were embedded $4 \mathrm{~mm}$ apart, with only their tips in electrical contact with sea-water. Recordings were made at 100 or $200 \mu \mathrm{m}$ as for the oxygen but the actual resolution is lower. Laboratory tests showed that the resistivity signal in water overlying a flat sediment surface increases at a distance of $4-5 \mathrm{~mm}$, which is the limit of the vertical resolution in detecting the sediment-water interface. Nevertheless, in the sediment, the 
electrical field between the measuring wires decreases because of the presence of mud and the resolution increase and becomes better than 4-5 $\mathrm{mm}$ in sediment although difficult to estimate accurately (Andrews and Bennet, 1981). We estimate the vertical depth resolution of the resistivity signal in the sediment to be 1 or $2 \mathrm{~mm}$. Voltage output were first calibrated to resistivity using measurements in standards solutions made of $\mathrm{KCl}$. Resistivity recordings were then converted to inverse formation factor $\left(\mathrm{F}^{-1}\right)$ values (Berner, 1980):

$$
F^{-1}=R_{b w} / R_{z}
$$

where $R_{b w}$ is the average resistivity in bottom water and $R_{z}$ the mean resistivity at a given depth $z$. The inverse formation factor has been translated into porosity values using the empirical Archie relation: $\mathrm{F}^{-1}=\phi^{\mathrm{m}}$ where $m$ is determined experimentally depending on sediment type (Ullman and Aller, 1982). Different values of $m$ were tested and porosities recalculated from resistivity compared to the measured porosity profiles.

\subsection{Core measurements}

Sediment were sampled with a multicorer equipped with Plexiglas tubes of internal diameter of $10-\mathrm{cm}$ diameter, 60-cm long (Barnett et al., 1984). Total core length was between 25 and $32 \mathrm{~cm}$. Sediment cores were stored in a cold room at $4^{\circ} \mathrm{C}$ just after recovery.

\subsubsection{On board oxygen profiles}

Undisturbed sediment cores were kept in the cold room at $4^{\circ} \mathrm{C}$ until brought to the measurement lab at room temperature $\left(20^{\circ} \mathrm{C}\right)$. After this transfer, micro-profiles were quickly performed (within $1 \mathrm{~h}$ ) with $\mathrm{O} 2$ microelectrodes mounted on a motor-driven micromanipulator interfaced to a computer (Revsbech and Jorgensen, 1986). The $\mathrm{O} 2$ microelectrodes were of Clark type, with an internal reference and an outer tip diameter of 40 to $60 \mu \mathrm{m}$ (Unisense). Calibration was performed using the same methods as in situ electrodes.

\subsubsection{Elemental analysis of the solid phase}

The analysis of the sediment composition was made on core which was sectioned into 0.5$\mathrm{cm}$ slices down to $5 \mathrm{~cm}$, followed by $1-\mathrm{cm}$ slices from 5 to $10 \mathrm{~cm}$ and finally 2-cm slices below $10-\mathrm{cm}$ depth. Sediment samples were packed in pre-weighed plastic bags and frozen on board. In the laboratory, slices of wet sediment in each bag were weighed, and then were freeze dried and weighed again to calculate the water content of samples. Micro-profiles of porosity were also performed on microcores subsampled using sharpened $50-\mathrm{ml}$ syringes. This provided porosity profiles at a $2-\mathrm{mm}$ resolution in the first $5 \mathrm{~cm}$. Total nitrogen and total carbon were determined in duplicate with a Leco CNS-2000 auto-analyzer. Organic carbon concentration was directly measured with a Leco WR12 elemental analyzer after removing carbonates with a $2 \mathrm{~N} \mathrm{HCl}$ solution without rinsing. Inorganic carbon content was calculated by difference. Analysis of the chemical composition of particles was undertaken by EDAX I DX-4i X-ray spectrometry. Standards were prepared in the laboratory from pure chemical compounds. Particles and standards were strongly compressed (5 tons) to obtain a pellet of $3 \mathrm{~mm}$ in diameter with a very flat surface. The analytic accuracy was $5 \%$ for the elements with a concentration $>1 \%$. The element concentrations are reported in terms of weight percentage of dry particles or sediment (wt\%).

\subsubsection{Radionuclides measurements}

Sediment samples for radionuclide investigations were vertically sliced at 0.5 and 1-cm intervals aboard the ship and then stored in polyethylene bags. Back in the laboratory, sediment samples were dried at $110^{\circ} \mathrm{C}$ and ground in an agate mortar prior to sealing in 
polyethylene tubes, ready for gamma counting. The activities of ${ }^{234} \mathrm{Th},{ }^{228} \mathrm{Th},{ }^{210} \mathrm{~Pb},{ }^{226} \mathrm{Ra}$, ${ }^{228} \mathrm{Ra},{ }^{137} \mathrm{Cs}$ and ${ }^{238} \mathrm{U}$ were measured on $2-4 \mathrm{~g}$ of dried sediment using the specific gamma rays (Legeleux et al., 1994). Counting was conducted using three high-efficiency, lowbackground Well-type Ge detectors (active volume 215, 430 and $980 \mathrm{~cm}^{3}$ ) at the Laboratoire Souterrain de Modane (LSM) in the French Alps (Reyss et al., 1995). The standards used to calibrate the gamma detectors are several IAEA standards: RGU-1, RGTh-1 and a mock-up of sediment with $U$ and Th standards from the NBS at $1000 \mathrm{ppm}$. The counting of small samples considerably reduces the self-absorption effects for the detection of low-energy gamma ray such as the $46.5 \mathrm{keV}$ for ${ }^{210} \mathrm{~Pb}$. For the very top 0 to $2 \mathrm{~cm}$ depth in the cores two counting stages were conducted, the first as soon as possible after sampling (less than six weeks) for the determination of the short half-lived ${ }^{234} \mathrm{Th}_{\mathrm{xs}}\left(\mathrm{T}_{1 / 2}=24.1 \mathrm{~d}\right)$ (Schmidt et al., 2002) and a second one later for the other radionuclides of interest.

\subsection{Vertical particles fluxes}

The settling particles were collected using cone-shaped traps with 24 collection bottles (Technicap $\AA$ ). These traps have a sampling aperture of $1 \mathrm{~m}^{2}$ covered with a honeycomb baffle of $1 \mathrm{~cm}$ diameter and 10-cm-deep cells. Prior to deployment, the sampling bottles were filled with filtered sea water containing sodium borate buffered formalin to give a final concentration of 3\% in order to prevent in situ microbial decomposition (Lee et al., 1992). On recovery, samples were stored in the dark at $4^{\circ} \mathrm{C}$ pending analyses.

The particles were collected by time-series sediment traps attached 30 and $400 \mathrm{~m}$ above the bottom (a.b.) on the stations A, C and D. The traps were placed on a single mooring deployed four consecutive times from March 2000 to January 2005. At the station R, one sediment trap at $400 \mathrm{~m}$ a.b. was deployed only between February and May 2005. The sampling interval was 10 or 15 days. Current meters were attached $10 \mathrm{~m}$ above each trap and recorded current velocities for the whole duration of particle collection. The position and depth of the moorings are given in Tables 1 and 2 .

\section{Results}

\subsection{Sediment composition}

Porosity of the superficial sediment $(0-0.5 \mathrm{~cm})$ varied from 0.91 at Lobe station to 0.97 at $\mathrm{C}$ station (Fig. 3). It decreases rapidly down to $5-7 \mathrm{~cm}$ and then remains constant under this limit at an average porosity of 0.90 . Station Lobe displays a different profile and does not present any decrease of porosity until $17 \mathrm{~cm}$. High-resolution porosity profiles measured on small subcores were combined with in situ resistivity measurements (Fig. 4). Recalculated inverse formation factors $\left(\mathrm{F}^{-1}\right)$ display sharp gradients at the sediment-water interface and decrease down to 0.6 to 0.7 . Profiles of $\mathrm{F}^{-1}$ also displays some decrease in the water column above the sediment, which is a known artefact previously described in (Andrews and Bennet, 1981). Archie's law $\left(F^{-1}=\phi^{m}\right)$ was used to recalculate porosity from the inverse formation factor by trying different $m$ values to find the best fit to the observed porosity. In most instances, the reported value for muddy sediment $(m=3$; Ullman and Aller, 1982) was inadequate to fit the observed porosity (Fig. 4). When a higher value of $m$ was used $(m=4)$, the fit with the observed porosity was better indicating that higher values than that reported in Ullman and Aller (1982) can apply for deep-sea muds.

The organic carbon content is quite high in this margin's sediments and varied from $3.45 \%$ (station Lobe) to $1.3 \%$ (station C) of dry sediment at the surface. According to sediment traps (see below), organic debris carried down with siliceous skeletons of radiolaria and diatoms and zooplankton faecal pellets were the main sources of organic carbon in the sediment (Marchig et al., 2001). The organic carbon concentration does not decrease with depth in the sediment as it is generally observed in the deep-sea. On the contrary, the 
general trend demonstrates a slight increase of organic carbon with a maximum around 10 cm depth.

Total nitrogen profiles are similar to the organic carbon variations into the sediment (Fig. 3).

The organic $\mathrm{C}$ : $\mathrm{N}$ ratio (Fig. 3) depends of the station location and the origin of the organic matter redeposited. The higher $\mathrm{C}: \mathrm{N}$ ratio at the surface sediment is observed at the stations $\mathrm{R}, \mathrm{D}$ and Lobe (respectively, 10.6, 11.3 and 13.8). The lower $\mathrm{C} / \mathrm{N}$ is measured at the stations Tete, $A$ and $C$ (respectively, 8.9, 7.8 and 8.5), more influenced by the marine organic matter. Inorganic carbon concentration in the solid phase is particularly low with a maximum of $0.9 \%$ $\left(7.5 \% \mathrm{CaCO}_{3}\right)$ at the shallow station (Tete) and a minimum at the station $\mathrm{C}(0.3 \% \mathrm{C} ; 2.5 \%$ $\mathrm{CaCO}_{3}$ ). The particularity of this last station was the large increase of carbonate content from 7 to $27 \mathrm{~cm}$ depth.

\subsection{Particle flux}

Daily mass fluxes at $400 \mathrm{~m}$ a.b. calculated from the 4-year dataset are 123.2, 67.2 and 80.7 $\mathrm{mg} \mathrm{m}^{-2} \mathrm{~d}^{-1}$, respectively, at stations $A, C$ and $D$ (Table 3). At station $R$, the total flux is 141.3 $\mathrm{mg} \mathrm{m}^{-2} \mathrm{~d}^{-1}$ measured during only four months. Close to the bottom (30 m a.b.), the average total flux is higher than at $400 \mathrm{~m}$ a.b. due to sediment resuspension close to the nepheloid layer at station A, C and D. Concerning trapping efficiency, deep current speed was weak in the investigated area during the four years of measurement and did not interfere significantly with the catching efficiency of the sediment trap. Indeed, current speed $<15 \mathrm{~cm} \mathrm{~s}^{-1}$ represents $99 \%$ of the total record at the deepest stations C and D and $92 \%$ at station A (Vangriesheim et al., 2009).

Figure 5 shows the temporal variations of the mass and POC flux at the four stations. Large inter-annual variations were noticeable at the shallow station A. For example, the total flux was twice as high in $2002\left(167.5 \mathrm{mg} \mathrm{m}^{-2} \mathrm{~d}^{-1}\right)$ than in 2001 (83.9 $\left.\mathrm{mg} \mathrm{m}^{-2} \mathrm{~d}^{-1}\right)$. This difference was the result of 3 large inputs of material (maximum flux above $400 \mathrm{mg} \mathrm{m}^{-2} \mathrm{~d}^{-1}$ ) in January, June and October 2002. In contrast, only one peak was measured in July 2003. During the 4 years of measurement, the channel overflow was observed once at station $D$ in March 2001 (Khripounoff et al., 2003). At this period, the particle flux increased suddenly from 54 to $3300 \mathrm{mg} \mathrm{m}^{-2} \mathrm{~d}^{-1}$ in the sediment trap positioned at $30 \mathrm{~m}$ a.b.. However, this flux increase was not observed at $400 \mathrm{~m}$ a.b.

The total flux shows less variation at station $\mathrm{C}$. When compared to station $\mathrm{A}$, the variation of mass fluxes at station $C$ is damped with maximum values below $150 \mathrm{mg} \mathrm{m}^{-2} \mathrm{~d}^{-1}$, whereas maximum values at station A exceeds $400 \mathrm{mg} \mathrm{m}^{-2} \mathrm{~d}^{-1}$. A power density spectrum analysis of the periodicity of flux temporal fluctuations at this station indicates the existence of a periodicity of 1 year for the flux variation with a maximum in summer and a minimum in winter.

The importance of silicate in settling particles is the main particularity of the Angola margin particles (Fig. 6) with the presence of numerous diatoms and radiolarian skeletons. Together with alumino-silicate and carbonate (around 25-40\% carbonate d.w. 3-5\% inorganic carbon), they represent $80 \%$ of the vertical flux with organic matter being around $20 \%$ in the trap material: organic carbon average concentration from $8.1 \%$ at station $A$ to $6.1 \%$ at station $\mathrm{D}$. In the sediment, as it is generally observed, a large shift towards alumino-silicate is observed with a decrease of organic and inorganic carbon at all stations when compared to trapped particles, indicating organic matter remineralization and carbonate dissolution.

\subsection{Oxygen profiles measured in situ and on board}

Figure 7 shows the vertical oxygen distribution measured in the porewaters using both the onboard and in situ micro profiler for station A, C, D and R and with the onboard microprofiler only for station Tete and Lobe (Fig. 7). Station A is characterized by an unusually high heterogeneity which might be due to the occurrence of a large burrow at the measurement 
spot. Some profiles show a sharp gradient at the sediment-water interface with a subsurface increase in concentration which is typical of a profile through a diagonal burrow with organicrich faeces at the sediment surface (Wenzhöfer and Glud, 2004). The in situ profiles that look less affected by this burrow structure display an oxygen penetration depth (OPD) of 2.5-3 $\mathrm{cm}$. On board profiles performed on cores look similar to these last profiles with a large heterogeneity and show penetration ranging from 1.2 to $2.6 \mathrm{~cm}$. This oxygen penetration falls in the range reported by Wenzhöfer and Glud (2002) for this water depth on this margin. Further calculations of diffusive oxygen uptake were obtained from the profiles which look unaffected by the burrow.

Station $\mathrm{C}$ shows more homogeneity and a deeper OPD, although this can not be fully assessed due to a technical lack of data between 6 and $8 \mathrm{~cm}$. The oxygen profiles obtained in situ penetrate down to $6 \mathrm{~cm}$ with a low gradient at the sediment-water interface. The onboard profiles display steeper gradients but did not reach full penetration of $\mathrm{O}_{2}$ due to the restricted depth range in our on board setting.

For station D, a better homogeneity of profiles is observed with lower OPD compared to station C. Indeed, penetration ranges between 2.8 and $3.8 \mathrm{~cm}$. On board profiles are similar in shape to in situ profiles.

Station $\mathrm{R}$ shows a lower oxygen penetration than station $\mathrm{C}$ and $\mathrm{D}$ since it is restricted to 1.7 to $2.3 \mathrm{~cm}$. In situ profile displays a fair homogeneity and are clearly different from the on board profile which show deeper penetrations $(>2.5 \mathrm{~cm})$ and smaller gradients.

For the Tete and Lobe stations, a set of three on board profiles is available for each station. Tete station is located near the shelf break $(334 \mathrm{~m})$ in the oxygen minimum zone. It thus displays a low oxygen concentration in the overlying water $\left(79 \mu \mathrm{mol} \mathrm{I}^{-1}\right)$ and a low oxygen penetration depth $(6-8 \mathrm{~mm})$. More surprising is the low OPD measured at the Lobe station located at $4800 \mathrm{~m}$ depth. All three oxygen profiles measured on the same core penetrate to the same depth (1.5-2 $\mathrm{mm}$ ) which indicates large oxygen consumption at this site.

\subsection{Total oxygen uptake measured in situ}

Figure 8 presents examples of chemical oxygen analysis and optode records of water isolated under a benthic chamber of the RAP2 at each station. We find a good agreement between these two analytical methods. The curve slope on these graphs indicates the in situ consumption rate and must be corrected by the precise volume of water incubated in each chamber. At station D, the consumption slope was not linear after $30 \mathrm{~h}$. The reason of this observation could be related to the final oxygen concentration which was lower than $80 \%$ of the initial value during this experiment at $D$.

\subsection{Comparison of total and diffusive oxygen fluxes in the area}

Oxygen fluxes estimated from the in situ measurements performed during the Biozaire 3 campaigns are plotted on Fig. 9. Both DOU and TOU display a bathymetric decrease from larger values measured at $1300(\mathrm{~A})$ and $3150 \mathrm{~m}(\mathrm{R})$ to lower fluxes measured at $4000 \mathrm{~m}$ (C and $D$ ). Total fluxes are, in all cases, larger than diffusive fluxes as total fluxes include processes such as bio-irrigation or non diffusive uptake which can be very active in continental margin (Wenzhöfer and Glud, 2002). All estimations of $\mathrm{O}_{2}$ fluxes are reported in Table 4, with DOU calculated from in situ and on board profiles and TOU measured on two different field campaigns (2001 and 2003) on the same set of stations except station R. On board DOU differs from in situ DOU for only one station $(C, 4000 \mathrm{~m})$. All the other stations display a fair comparison between in situ and onboard DOU. Except for station C, TOU measured on two different years show a good agreement (i.e. at station $A$, for $p<0.05$ ), which indicates that the system is stable over time and that spatial variability at the station level is captured by the RAP2 benthic chamber measurements. Station C shows an increase by $50 \%$ between 2002 and 2003 (student test valid with $n=5$ and $p<0.01$ ). At the Tete station, the oxygen demand is low due to the oxygen minimum in the water column at this depth. Lobe station shows a very large oxygen demand, which agrees with the sharp gradient observed 
on the vertical distributions. TOU/DOU ratios are quite constant over the stations with a value of 1.5 typical of deep-sea values except for station $C$ which shows a value of 3 .

\subsection{Radionuclides and sedimentation rates in the area}

Profiles of ${ }^{226} \mathrm{Ra},{ }^{228} \mathrm{Ra},{ }^{210} \mathrm{~Pb}_{\mathrm{xs}}$ and ${ }^{228} \mathrm{Th}_{\mathrm{xs}}$ versus depth in the cores are plotted in Figure 10. ${ }^{234} \mathrm{Th}$ (data not shown) and ${ }^{228} \mathrm{Th}$ excesses of several $\mathrm{dpm} \mathrm{g}^{-1}$ (disintegration per minute per gram) were detected at the top $0-1.5 \mathrm{~cm}$ of all the different cores providing evidence for a good recovery of the interface sample. ${ }^{228} \mathrm{Ra}_{\mathrm{xs}}$ show a large increase with depth at station $\mathrm{A}$ and $D$ with peaks around $5 \mathrm{~cm}$, whereas ${ }^{226} \mathrm{Ra}_{\mathrm{xs}}$ displays the same feature at station $\mathrm{C}$ and D.

The top $10 \mathrm{~cm}$ of the cores are affected by several processes such as bioturbation, diagenesis, compaction that disturbs the radionuclide distribution and therefore omitted in the calculation of sedimentation rates using radionuclide distributions. Net linear sedimentation rates calculated from ${ }^{210} \mathrm{~Pb}_{\mathrm{xs}}$ profiles for station $\mathrm{A}, \mathrm{C}, \mathrm{D}, \mathrm{R}$ and Tete, respectively $0.95,1.0$, $1.2,2.0$ and $1.0 \mathrm{~mm} \mathrm{y}^{-1}$, can be considered as very similar. When combined using porosity reported in Fig. 3 and a density of $2.65 \mathrm{~g} \mathrm{~cm}^{-3}$ commonly measured for alumino-silicate, values of sediment accumulation rates of $0.045,0.026,0.018,0.069,0.066 \mathrm{~g} \mathrm{~cm}^{-2} \mathrm{y}^{-1}$ are calculated for the same stations. The Lobe station shows a very different ${ }^{210} \mathrm{~Pb}_{\mathrm{xs}}$ activity profile which is almost constant over the top $20 \mathrm{~cm}$ pointing towards a higher sedimentation rate. If we use the profile of the shorter half-lived ${ }^{228} \mathrm{Th}_{\mathrm{xs}}$ as resulting from radioactive decay with time, a sedimentation rate of $19 \mathrm{~mm} \mathrm{y}^{-1}$ is calculated. The equivalent accumulation rate is $0.45 \mathrm{~g} \mathrm{~cm}^{-2} \mathrm{y}^{-1}$.

\section{Discussion}

\subsection{Sediment oxygen fluxes in the vicinity of the Congo channel and the Angola margin}

Before this study, a restricted number of in situ measurements of sediment oxygen fluxes had been performed on the Congo fan area and the margins north and south. Only one in situ station is reported in Glud et al. (1994) and Wenzhöfer and Glud (2002) at $3100 \mathrm{~m}$ (station 1702) and three stations at $1300 \mathrm{~m}$ (station 4909, 4913 and 4917). These latter stations are located on the northern side of the Congo channel at a distance of 400 and 50 $\mathrm{km}$ from the channel for stations 4909 and 4913, respectively, and on the southern side at $600 \mathrm{~km}$ for station 4917 (see Fig. 1 for stations 1702 and 4913).

A compilation of TOU and DOU results from this study and former values with trends observed for different Atlantic and Pacific margins is proposed in Figure 11. The different curves represent regressions on TOU calculated by Jahnke and Jackson (1987) for the western Atlantic and eastern Pacific, whereas the Wenzhöfer and Glud (2002) regression relies on DOU for the eastern Atlantic. This graph clearly shows that the non-upwelling margin regression does not apply to the data for the Angola margin. Indeed, the section of the margin studied during this work encompasses the Congo plume and the Angola upwelling zone, which create large primary production in their vicinity and larger deposition of organic matter in the sediment (Antoine et al., 1996). This is well illustrated at $1300 \mathrm{~m}$ depth where total oxygen fluxes (TOU) are higher than the regression for the overall margin. They show a large scatter with values ranging from 3 to $5.1 \mathrm{mmol} \mathrm{m}^{-2} \mathrm{~d}^{-1}$ in historical data and compare well with station $\mathrm{A}$ ( 3.2 to $4 \mathrm{mmol} \mathrm{m}^{-2} \mathrm{~d}^{-1}$ ).

For deeper stations, total oxygen fluxes fall closer to the regression calculated for upwelling margins either the eastern Pacific or eastern Atlantic. The results from this study at intermediate depths $(3000 \mathrm{~m})$ are still higher than these regressions. Indeed, values of 1.6$1.8 \mathrm{mmol} \mathrm{m}^{-2} \mathrm{~d}^{-1}$ are reported for TOU at station 1702 located at $3100 \mathrm{~m}$ and agree with the regression for this margin (Wenzhöfer and Glud, 2002). The oxygen demand at station R (3.6 $\mathrm{mmol} \mathrm{m} \mathrm{m}^{-2} \mathrm{~d}^{-1}$ ) is significantly higher than this value. This could be due to lateral heterogeneity 
or due to the location of station $\mathrm{R}$ in the vicinity of the Congo channel. which is prone to receive turbidites overflowing the channel. Indeed, the wall's height falls below $250 \mathrm{~m}$ at $3000 \mathrm{~m}$ depth allowing local channel overflow in case of large turbidite. Additionally, station $\mathrm{R}$ is located near a giant cold-seep site (Regab; Olu-Le Roy et al., 2007), which is known as an ecosystem producing a large quantity of fresh organic material, but the input of this material to site R is still uncertain. Station 1702 is located $80 \mathrm{~km}$ south of the Congo channel and away from the cold-seep zone and does not receive such inputs.

The TOU measured at 4000 agrees with the regression of Jahnke and Jackson (1987) for the upwelling Pacific and with the values found by Jahnke et al. (1990) in the eastern Pacific margin, with increased mineralization rates found in sediments located at the base of the continental slope.

Surprisingly, station $D$, which is located near the channel levee and receives substantial amount of particles from turbidite flows (Fig. 5, March 2001), does not display a larger oxygen demand than station $C$ located $200 \mathrm{~km}$ south of the Congo channel. This indicates that station $C$ receives an equivalent input of organic matter presumably by downslope transport as has been proposed by Jahnke et al. (1990) for the eastern Pacific margin. A first clue is found in the fluxes at $30 \mathrm{~m}$ high, which are twice those at $400 \mathrm{~m}$ high. Large episodic inputs of organic matter at this site are indicated by an increase in TOU between 2001 and 2003 (Table 4) and by the doubling during the same period of macrofaunal population density driven by food supply as reported in Galéron et al. (2009). In addition, the shape of the oxygen profiles at station $\mathrm{C}$ with a sharp gradient at the sediment-water interface and a deep penetration (down to 7-8 cm, Fig. 7) suggest a recent input of fresh organic carbon (Rabouille et al., 1998, 2001b). These arguments suggest that Station C located at the bottom of the slope away from the channel receives episodically substantial inputs of labile organic matter, as, for example, between 2001 and 2003. It is noteworthy that these inputs are poorly recorded in 300-m-high sediment traps and must be related to lateral transport close to the bottom $(<400 \mathrm{~m})$.

\subsection{Organic carbon mass balance : vertical flux versus lateral inputs}

In order to elaborate on the driving processes affecting particulate organic carbon in the sediment of this margin (mode of input, relative magnitude of mineralization versus burial), we calculate mass balances for organic carbon at each station. Fluxes of organic carbon from the sediment traps deployed in the vicinity of the channel or on the Angola margin are compared to mineralization rates calculated from benthic oxygen fluxes (TOU) and burial rates obtained from net sedimentation rates, porosity and organic carbon content of the sediments (Table 5). Vertical POC fluxes were estimated from long-term series of sediment traps deployed in the area (Table 2). Except for station R (4-month deployment), most stations were investigated for four years at two different depths (30 and 400 m.a.b. Table 3). We chose trap fluxes at $400 \mathrm{~m}$ to reflect vertical fluxes from the surface ocean and avoid resuspension events that are known to be caught in sediments traps deployed closer to the sediment (Khripounoff et al., 1998). The calculated average organic carbon fluxes at station $C$ and D are comparable with trap measurements made at these depths in the mesotrophic Atlantic (Lampitt and Antia, 1997; Bory et al., 2001). They are also in the same magnitude than those measured by Fischer et al. (2000) and Wefer and Fischer (1993) at similar depths in the same region. The mean total flux measured on the station $A$ is also comparable with the South Atlantic model proposed by Seiter et al. (2005). Our results indicate the importance of long-term measurements to obtain a thorough estimation of the material input in continental slope area. Long-term measurement also allows assessing in more detail the possible periodical amount of material reaching the bottom. At station $C$, seasonality in organic carbon input is found with a maximum in boreal summer. This result is in agreement with the compilation of primary production values proposed by Antoine et al. (1996).

Mineralization rates were estimated from total oxygen uptake averaged over the two years of measurements (Table 4). A stoechiometric coefficient $\left(\mathrm{O}_{2}: \mathrm{C}\right)$ of 1.2 was used to calculate 
organic carbon mineralization from $\mathrm{O}_{2}$ fluxes as the $\mathrm{C}: \mathrm{N}$ ratio was between 8 and $10\left(\mathrm{O}_{2}: \mathrm{C}=\right.$ $1+2 / C: N$; Froelich et al., 1979). The anoxic mineralization is not explicitly taken into account as (i) anoxic mineralization is minimal in this type of sediments ( $<10 \%$; Bender and Heggie, 1984) and (ii) oxygen fluxes at the sediment-water interface include re-oxidation of anoxic mineralization (Canfield et al., 1993) by products and thus partly account for anoxic mineralization.

Burial rates were calculated using net sedimentation rates estimated by ${ }^{210} \mathrm{~Pb}_{\mathrm{xs}}$ below the bioturbation zone (Fig. 10). The following formula was applied

Accu $=\omega(1-\phi) \rho_{\mathrm{s}}$ OrgC/MM

with Accu the burial rate of $O C$ in $m o l ~ m^{-2} y^{-1}, \omega$ the linear sedimentation rate in $\mathrm{m} \mathrm{y}^{-1}, \phi$ the porosity, $\rho_{\mathrm{s}}$ the density of the solids in $\mathrm{gm}^{-3}$, OrgC the organic carbon content in dry weight $\mathrm{gC} \mathrm{g}^{-1}$, and MM the molar mass of carbon $12 \mathrm{~g} \mathrm{~mol}^{-1}$.

Except for the Lobe station, sedimentation rates measured in the present work, about $1 \mathrm{~mm}$ $\mathrm{y}^{-1}$ are similar to those reported for other continental margin deposits like for instance PeruChile (Munoz et al., 2004) or Iberian Margin (Jouanneau et al., 2002). Porosity and organic carbon content were averaged over the depth $15-20 \mathrm{~cm}$ to calculate burial fluxes. Sediment dry density was assumed to be equal to the quartz density $\left(2.65 \mathrm{~g} \mathrm{~cm}^{-3}\right)$.

From these estimations of annual fluxes, we calculated an unsupported flux by subtracting the vertical input flux to the sum of mineralization plus burial:

Unsupported flux $=($ Mineralization + Burial) - POC vertical flux

For all stations this unsupported flux is much larger than the input flux (Table 5). This is quite a common feature in the deep-sea for short-term trap measurements, but fluxes and sediment mineralization can be reconciled in some cases with longer trap measurements (Smith, 1987; Smith et al., 1992; Smith and Kaufmann, 1999). The large values of unsupported flux and the ratio of this flux to the vertical flux of 5 to 8 indicate that other substantial sources of inputs are needed to explain the observed mineralization and burial rates at each station which is much larger than the vertical flux. Mass balances of biogenic silica at the same sites displayed similar ratio (Regaudie de Gioux et al., 2009). In the context of a margin slope and furthermore in the vicinity of a canyon, dwnslope inputs are definitely a mode of transfer to consider. Some fractions of this flux are captured by sediment traps at $30 \mathrm{~m}$ since the flux at this depth is consistently twice as much as the flux at $400 \mathrm{~m}$. However, the flux recorded at $30 \mathrm{~m}$ a.b. does not bridge the gap and other processes occurring closer to the sediment must effectively transfer organic carbon through the slope.

The transfer from the channel is quite obvious for station D with the event of March 2001 (Fig. 5, and Khripounoff et al., 2003). The effect of the channel overflow at station D was well marked by an increase of organic matter in surface sediments which was still observable 9 months after the event but disappeared 2 years later (Treignier et al., 2006). For station C and $A$, the transfer mechanisms are less clear and may involve down slope transport in the bottom boundary layer over the whole slope from $1300 \mathrm{~m}$ down to $4000 \mathrm{~m}$. This downslope transport relate to the conclusion of the previous section which showed the intensification of organic matter recycling at the base of the slope near the Angola margin.

More evidence of the lateral input of material can be found in the comparison of the mass flux of particles with sedimentation rates in the core. Indeed, the total solid accumulating should be lower than the solid input by particle flux, knowing that organic matter will be degraded, and calcium carbonates and opal dissolved at the sea floor (Fig. 6). The calculation can be made using the following

MaxAccu $=$ Mass flux/(1- $\Phi) \rho_{\mathrm{s}}$

where MaxAccu is burial without dissolution or mineralization, $\Phi$ is the sediment porosity, and $\rho_{\mathrm{s}}$ is the solid dry density. Calculations for Station C, D and A with porosities from Fig. 3 at 15 $\mathrm{cm}$ depth, mass fluxes at $400 \mathrm{~m}$ and a dry density of $2.65 \mathrm{~g} \mathrm{~cm}^{-3}$ provide MaxAccu values of $0.12,0.08,0.09$ and $0.16 \mathrm{~mm} / \mathrm{yr}$, respectively. These values represent less than 10 to $15 \%$ of the net sedimentation rate observed for these sites (around $1 \mathrm{~mm} \mathrm{y}^{-1}$; Fig. 10). Since this estimate does not take into account the loss of opal and calcite by dissolution thus 
constituting a potential accumulation rate, the input of solid through downslope transport must definitely be very large to bridge the gap. It is, again, noteworthy that the flux at 30meters although larger than the flux at $400 \mathrm{~m}$ does not close the budget.

The partitioning between mineralization and burial of the organic input is quite atypical for sediments from this depth, with burial accounting for $30-50 \%$ of the total input of organic carbon due to very large sedimentation rates on the whole margin $\left(1 \mathrm{~mm} \mathrm{y}^{-1}\right)$. This is quite different from overall burial yield (1-5\%) at other sites especially at $4000 \mathrm{~m}$ (Berger et al., 1989; Canfield, 1994; Jahnke, 1996). In this regard, a clear distinction can be made between stations located near the channel (R and $D$ ) which show a burial/mineralization ratio of 1 and the stations located on the slope away from the channel (A and $C$ ), which display a ratio of 0.5 . This might be due to the quality (labile vs. refractory) of the organic matter transported to the sites near the channel which contains more terrestrial organic carbon than at the sites on the margin (Treignier et al., 2006). The larger terrestrial fraction at station D (and possibly R) would induce larger burial at these sites relative to slope sites.

\subsection{Transfer of organic carbon through the channel}

One striking feature of the Congo canyon system is the depth of the channel trench and its ability to carry material through turbidity currents down to the abyssal plain (Khripounoff et al., 2003). These turbidity currents channel the transfer of organic matter from the Congo River and shelf to the abyss. One issue which this transfer raises is the quantity, quality and fate of this organic carbon carried by turbidity currents. Is the transferred organic carbon labile or refractory? Is it buried in sediments, in the abyssal plain or is it mineralized by fauna and bacteria at the deep-sea floor where it gets deposited?

Although we have only a limited set of data relying uniquely on onboard oxygen profiles, we can approach this question. Figure 11 shows that station Lobe oxygen fluxes are much larger than other oxygen fluxes for the margin and even larger than fluxes generally reported for this depth $(4800 \mathrm{~m})$. This station is located at the outflow of the submarine channel where turbidites originating from the canyon are deposited in lobes. As has been shown before for on board set ups, these measurements can be biased by a factor of 1.5 to 2 compared to in situ results at $4800 \mathrm{~m}$ depth as reported by Glud et al. (1994), with onboard DOU being generally larger than in situ DOU due to compaction during coring or core warming and decompression during recovery. This is the case in our study where on board and in situ DOUs agree within 50\% (Table 4) with the exception of Station C. Even if the calculated DOU is overestimated, it represents a much larger oxygen demand than any other location at this depth. A mineralization rate of $6 \mathrm{~mol} \mathrm{C} \mathrm{m}^{-2} \mathrm{y}^{-1}$ is calculated for these sediments using 20 mmol m $\mathrm{m}^{-1}$ as oxygen demand and 1.2 as $\mathrm{O}_{2}: \mathrm{C}$ ratio. This large value indicates that a substantial proportion of the carbon carried down through the channel is mineralized in the abyssal plain sediments after deposition. Other parameters argue in favour of a very active site at the Lobe station. Organic carbon contents and sedimentation rates are very high indicating large inputs of organic material. The ROV video survey showed the presence of large terrestrial detritus on the sediment surface and explains its richness in organic material together with a large megafaunal density and bacterial mats indicative of large biological activity (M-C. Fabri, personnal communication).

At the Lobe site, which has a very high recent sedimentation rate $\left(>1 \mathrm{~cm} \mathrm{y}^{-1}\right)$ and a large concentration of organic carbon ( $>3 \% \mathrm{~d} . \mathrm{w}$.), burial is also a large component of the mass balance. The occurrence of very large $\mathrm{C} / \mathrm{N}$ in the Lobe core (13.8) points towards a large fraction of terrestrial organic carbon in the sediment. Organic markers such as linear alcohols measured by Treignier (2005) show a large dominance of terrestrial markers over marine markers at this station. Indeed, the burial flux calculated for station Lobe is larger than the mineralization rate $\left(13 \mathrm{~mol} \mathrm{C} \mathrm{m}^{-2} \mathrm{y}^{-1}\right.$ versus $\left.6 \mathrm{~mol} \mathrm{C} \mathrm{m}^{-2} \mathrm{y}^{-1}\right)$. This is unique in the deep-sea and equivalent to burial rates of organic carbon in river deltas (Hedges and Keil, 1995; McKee et al., 2004) and references therein). The ${ }^{228} \mathrm{Th}_{\mathrm{xs}}$ data allow estimating burial rates over around 10 years (five periods). The values provided by (Dennielou and Jouanneau, accepted) show that such large sedimentation rates occur over the 100-yr timescale. 
Furthermore, the spatial coverage of the Lobe station in this study is more representative (five sites) and show consistently large sedimentation rates $\left(0.5\right.$ to $\left.1.2 \mathrm{~cm} \mathrm{y}^{-1}\right)$. If our Lobe cores are representative of the Lobe system, it could thus constitute a megaburial center in the deep-sea. With a reported surface area of $3000 \mathrm{~km}^{2}$ (Savoye, personal communication), this Lobe region could account for an accumulation of $0.4 \mathrm{Tg} \mathrm{y}^{-1}\left(1 \mathrm{Tg}=10^{12} \mathrm{~g}\right)$, a significant fraction of total carbon burial in the South Atlantic (1.8 Tg y ${ }^{-1}$; Mollenhauer et al., 2004) and of total deep-sea burial (10-20 Tg y ${ }^{-1}$; (Berner, 1989; Hedges and Keil, 1995)

A total of $19 \mathrm{~mol} \mathrm{C} \mathrm{m}^{-2} \mathrm{y}^{-1}$ could be deposited at the Lobe site mostly from the channel inputs. With the spatial extension of the Lobe system, this deposition could represent as much as $0.7 \mathrm{Tg} \mathrm{y}^{-1}$ around a third of reported particulate organic carbon input from the Congo River (1.9 $\mathrm{Tg} \mathrm{y}^{-1}$; Seylers et al., 2005).

\section{Conclusion}

Using a combination of techniques, we investigated the particulate organic carbon fluxes and recycling in the sediments from the Congo-Angola margin in the vicinity of the Congo channel and $200 \mathrm{~km}$ away. Vertical fluxes were measured using long-term sediment trap measurements and accumulation rates were derived from sedimentation rates estimated by short-live radioisotopes $\left({ }^{210} \mathrm{~Pb}_{\mathrm{xs}}\right.$ and $\left.{ }^{228} \mathrm{Th}_{\mathrm{xs}}\right)$ and organic carbon content of the sediment. Organic carbon recycling was estimated using a new combination of in situ techniques on a single platform (benthic chambers, microprofiler) and on board measurements of oxygen microprofiles. Results show a decreasing recycling of organic carbon when moving offshore and towards deeper waters, except for the Lobe site where recycling is 5-6 times larger.

From the results of this study, we conclude that, except for the Lobe zone situated in the abyssal plain at the outlet of the Congo channel, transfer processes across the margin are dominated by downslope transport and occasional channel overflow during turbidity currents. Downslope transport is largely superior to vertical input and contributes by $85 \%$ of the organic input at the slope rise. The lateral influence of the channel at a depth of $4000 \mathrm{~m}$ is minimal with mineralization/burial fluxes being equal at distances of 15 and $200 \mathrm{~km}$ from the channel (station C and D).

The Congo channel is an efficient conduit for river and shelf particles. Indeed, the Lobe region which is situated at the outlet of the Congo channel shows very large carbon mineralization and burial rates according to our preliminary data and could receive a significant proportion of the particulate organic carbon delivery by the Congo River (up to $30 \%$ ). This region is a significant site of organic carbon burial in the South Atlantic Ocean.

\section{Acknowledgments}

We thank the participants of the Biozaire cruises, and the captain and crew of the N/O Atalante, N/O Suroit and N/O Beautemps-Beaupré. Bruno Bombled and P. Noel are acknowledged for the technical assistance during the cruise Biozaire 3. Our thanks also go to M.C. Fabri for his information from the Biocean database (http://www.ifremer.fr/isi/biocean). We thank A. Vangrieshem, J. Galéron and K. Olu-Leroy for their unpublished data and inputs. This work was supported by IFREMER contract Biozaire to LSCE and by LSCE (CEA-CNRS). This is LSCE publication number XXXX.

\section{References}


Andersson, J.A., Mackenzie, F.T., 2004. Shallow-water oceans: a source or sink of atmospheric CO2? Front. Ecol. Environ. 2, 348-353.

Andrews, D., Bennet, A., 1981. Measurements of diffusivity near the sediment-water interface with a fine-scale resistivity probe. Geochim. Cosmochim. Acta 45, 2169-2175.

Antoine, D., André, J., Morel, A., 1996. Oceanic primary production-2. Estimation at global scale from satellite (coastal zone colour scanner) chlorophyll. Glob. Biogeochem. Cycles 10, 57-69.

Babonneau, N., Savoye, B., Cremer, M., Klein, B., 2002a. Morphology and architecture of the present canyon and channel system of the Zaire dees-sea fan. Mar. Petrol. Geol. 19, 445-467.

Babonneau, N., Savoye, B., Cremer, M., Klein, B., 2002b. Morphology and architecture of the present channel system of Zaire Deep-Sea Fan. Marine and Petroleum Geology 19 (4), 445-467.

Barnett, P.R.O., Watson, J., Conelly, D., 1984. A multiple corer for taking virtually undisturbed samples from shelf, bathyal and abyssal sediments. Oceanol. Acta 7, 257-263.

Bender, M.L., Heggie, D.T., 1984. Fate of organic carbon reaching the sea-floor: a status report. Geochim. Cosmochim. Acta 48, 977-986.

Berg, P., Risgaard-Petersen, N., Rysgaard, S., 1998. Interpretation of measured concentration profiles in sediment pore water. Limnol. Oceanogr. 43, 1500-1510.

Berger, W.H., Smetacek, V.S., Wefer, G., 1989. Ocean Productivity and Paleoproductivity An overview. In: W.H. Berger, V.S. Smetacek, G. Wefer (Eds.), Productivity of the oceans: present and past, Dahlem Konferenzen, John Wiley \& Sons, Berlin. pp. 1-34.

Berner, R.A., 1980. Early Diagenesis: A Theoretical Approach. Princeton University Press, Princeton, 241pp.

Berner, R.A., 1989. Biogeochemical cycles of carbon and sulfur and their effect on atmospheric oxygen over phanearozoic time. Pal. Pal. Pal. 73, 97-122.

Biscaye, P.E., Anderson, R.F., 1994. Fluxes of particulate matter on the slope of the southern Middle Atlantic Bight: SEEP-II. Deep-sea Res. 41, 459-509.

Bongo-Passi, G., 1984. Contribution à l'étude lithostratigraphique, minéralogique et géochimiques du delta sous-marin profond du fleuve Congo, Université de Toulouse, Toulouse (France), pp. 215 pp.

Bory, A., Jeandel, C., Leblond, N., Vangrieshem, A., Khripounoff, A., Beaufort, L., Rabouille, C., Nicolas, E., Tachikawa, K., Etcheber, H., Buat-Menard, P., 2001. Downward particle fluxes within different productivity regimes off the Mauritanian upwelling zone (EUMELI program). Deep-Sea Res. (I) 48, 2251-2282.

Canfield, D.E., 1994. Factors influencing organic carbon preservation in marine sediments. Chem. Geol. 114, 315-329.

Canfield, D.E., Jorgensen, B.B., Fossing, H., Glud, R., Gundersen, J., Ramsing, N.B., Thamdrup, B., Hansen, J.W., Nielsen, L.P., Hall, P.O.J., 1993. Pathways of organic carbon oxidation in three continental margin sediments. Mar. Geol. 113, 27-40.

Carritt, D.E., Carpenter, J.H., 1966. Comparison and evaluation of currently employed modifications of the Winkler method for determining dissolved oxygen in sea water. A NASCO Report. Journal of Marine Research 24, 286-318.

Dagg, M., Benner, R., Lohrenz, S., Lawrence, D., 2004. Transformation of dissolved and particulate materials on continental shelves influenced by large rivers: plume processes. Contin. Shelf Res. 24, 833-858.

Dedieu, K., Rabouille, C., Thouzeau, G., Jean, F., Chauvaud, L., Clavier, J., Mesnage, V., Ogier, S., 2007. Benthic $\mathrm{O} 2$ distribution and dynamics in a Mediterranen lagoon (Thau, France): An in-situ microelectrode study. Est. Coast. Shelf Sci. 72, 393-405.

Dennielou, B., Jouanneau, J.M., accepted. Ages and duration of sedimentary objects and sediment accumulation rates. In: N. Babonneau, B. Savoye, A. Morash (Eds.), Key results of integrated study of the modern Zaire/Congo Fan (ZaiAngo project). pp.

Fischer, G., Ratmeyer, V., Wefer, G., 2000. Organic carbon fluxes in the Atlantic and the SOuthern Ocean: relationship to primary production compiled from satellite radiometer data. Deep-sea Res. II 47, 1961-1997. 
Froelich, P.N., Klinkhammer, G.P., Bender, M.L., Luedtke, N.A., Heath, G.R., Cullen, D., Dauphin, P., Hammond, D., Hartman, B., Maynard, V., 1979. Early oxidation of organic matter in pelagic sediments of the eastern equatorial Atlantic: suboxic diagenesis. Geochim. Cosmochim. Acta 43, 1075-1090.

Galéron, J., Menot, Khripounoff, A., this volume. Benthic macrofauna communities at two deep sites in the Gulf of Guinea. Deep-Sea Res.

Glud, R.N., Gundersen, J.K., Jorgensen, B.K., Revsbech, N.P., Schultz, H.D., 1994. Diffusive and total oxygen uptake of deep-sea sediments in the eastern South Atlantic Ocean: in situ and laboratory measurements. Deep-Sea Res. 41, 1767-1788.

Goni, M.A., Ruttenberg, K.C., Eglinton, T.I., 1997. Sources and contribution of terrigenous organic carbon to surface sediments in the Gulf of Mexico. Nature 389, 275-278.

Hedges, J.I., Keil, R.G., 1995. Sedimentary organic matter preservation: an assessment and speculative synthesis. Mar. Chem. 49, 81-115.

Hedges, J.I., Keil, R.G., Benner, R., 1997. What happens to terrestrial organic matter in the ocean? Org. Geochem. 27, 195-212.

Heezen, B.C., Menzies, R.J., Schneider, E.D., Ewing, W.M., Granelli, N.C.L., 1964. Congo Submarine Canyon. AAPG Bulletin 48, 1126-1149.

Jahnke, R.A., 1996. The global ocean flux of particulate organic carbon: Areal distribution and magnitude. Glob. Biogeochem. Cycles 10, 71-88.

Jahnke, R.A., C.E. Reimers, Craven, D.B., 1990. Intensification of recycling of organic matter at the sea floor near ocean margins. Nature 348, 50-54.

Jahnke, R.A., Jackson, G.A., 1987. Role of sea floor organisms in oxygen consumption in the deep North Pacific Ocean. Nature 329, 621-623.

Jouanneau, J.M., Weber, Drago, T., Rodrigues, A., Oliviera, A., Dias, J.M.A., Garcia, C., Schmidt, S., Reyss, J.L., 2002. Recent sedimentation and sedimentary budgets on the Western Iberian Shelf. Progress in. Oceanography 52, 261-275.

Khripounoff, A., Caprais, J.-C., Crassous, P., 2006. Geochemical and biological recovery of the disturbed seafloor in polymetallic nodule fields of the Clipperton-Clarion Fracture Zone (CCFZ) at 5000m depth. Limnol. Oceanogr. 51, 2033-2041.

Khripounoff, A., Vangriesheim, A., Babonneau, N., Crassous, P., Savoye, B., Dennielou, B., 2003. Direct observation of intense turbidity current activity in the Zaire submarine valley at 4000 m water depth. Mar. Geol. 194, 151-158.

Khripounoff, A., Vangrieshem, A., Crassous, P., 1998. Vertical an temporal variations of particle fluxes in the deep tropical atlantic. Deep-Sea Res. 45, 193-216.

Kinga-Mouzeo, 1986. Transport particulaire actuel du fleuve Congo et de quelques affluents; enregistrement quaternaire dans l'éventail détritique profond (sédimentologie, minéralogie et géochimie), Doctorat, Univ. de Perpignan, Perpignan, pp. 251 pp.

Lampitt, R.S., Antia, A.N., 1997. Particle flux in deep seas: regional characteristics and temporal variability. Deep-Sea Res. 44, 1377-1403.

Lee, C., Hedges, J.I., Wakeham, S.G., Zhu, N., 1992. Effectiveness of various treatments in retarding microbial activity in sediment trap material and their effects on the collection of swimmers. Limnol. Oceanogr. 37, 117-130.

Legeleux, F., Reyss, J.-L., Schmidt, S., 1994. Particle mixing rates in sediments of the northeast tropical Atlantic: Evidence from 210Pbxs, 137Cs, 228Thxs and 234Thxs downcore distributions. Earth Planet. Sci. Let. 128, 545-562.

Marchig, V., von Stackelberg, U., Hufnagel, H., Durn, G., 2001. Compositional changes of surface sediments and variability of manganese nodules in the Peru basin. Deep-Sea Research 2 48, 3523-3547.

McCave, I.N., Hall, I.R., Antia, A.N., Chou, L., Dehairs, F., Lampitt, R.S., Thomsen, L., van Weering, T.C.E., Wollast, R., 2001. Distribution, composition and flux of particulate material over the European margin at $47^{\circ}-50^{\circ} \mathrm{N}$. Deep-sea Res. II 48, 3107-3139.

McKee, B., Aller, R.C., Allison, M.A., Bianchi, T.S., Kineke, G.C., 2004. Transport and transformation of dissolved and particulate materials on continental margins influenced by major rivers: benthic boundary layer and seabed processes. Contin. Shelf Res. 24, 899-926. 
Milliman, J.D., 1991. Flux and fate of fluvial sediment and water in coastal seas. In: R.F.C. Mantoura, J-M. Martin and R. Wollast (Ed.), Ocean margin processes in global change, Dahlem Workshop Reports, J. Wiley and sons, Berlin. pp. 69-91.

Mollenhauer, G., Schneider, R.R., Jennerjahn, T., Muller, P.J., Wefer, G., 2004. Organic carbon accumulation in the South Atlantic Ocean: its modern, mid-Holocene and last glacial distribution. Glob. Planet. Change 40, 249-266.

Munoz, P., Lange, C.B., Gutierrez, D., Hebbeln, D., Salamanca, M.A., Dezileau, L., Reyss, J.L., Benninger, L.K., 2004. Recent sedimentation and mass accumulation rates based on 210Pb along the Peru-Chile continent margin. Deep-Sea Res. II 51, 2523-2541.

Olu-Le Roy, K., Caprais, J.-C., Fifis, A., Fabri, M.C., Galéron, J., Budzinsky, H., Le Ménach, K., Khripounoff, A., Ondreas, H., Sibuet, M., 2007. Cold-seep assemblages on a giant pockmark off West Africa: spatial patterns and environmental control. Mar. Ecol. prog. Series 28, 115-130.

Rabouille, C., Denis, L., Dedieu, K., Stora, G., Lansard, B., Grenz, C., 2003. Oxygen demand in coastal marine sediments: comparing in situ microelectrodes and laboratory core incubations. J. Exper. Mar. Biol. Ecol. 285/286, 49-69.

Rabouille, C., Gaillard, J.-F., Relexans, J.-C., Treguer, P., Vincendeau, M.-A., 1998. Recycling of organic matter in Antarctic sediments: A transect through the Polar front in the Southern Ocean (Indian Sector). Limnol. Oceanogr. 43, 420-432.

Rabouille, C., Mackenzie, F., Ver, L.M., 2001a. Influence of the human perturbation on carbon, nitrogen and oxygen biogeochemical cycles in the global coastal ocean. Geochim. Cosmochim. Acta 65, 3615-3639.

Rabouille, C., Witbaard, R., Duineveld, G., 2001b. Annual and interannual variability of sedimentary recycling in the North Atlantic Ocean (BENGAL site) studied with a non-steadystate model. Progr. Oceanogr. 50, 147-170.

Regaudie de Gioux, A., Gallinari, M., Moriceau, B., Ragueneau, O., This volume. The 4000m silicate anomalie origin: study of biogenic silica in bottom water and at water-sediment interface.

Revsbech, N.P., 1989. An oxygen microsensor with a guard cathode. Limnol. Oceanogr. 34, 474-478.

Revsbech, N.P., Jorgensen, B.B., 1986. Microelectrodes: their use in microbial ecology. Adv. Microb. Ecol. 9, 293-352.

Reyss, J.L., Schmidt, S., Legeuleux, F., Bonte, P., 1995. Large low background well-type detectors for measurements of environmental radioactivity. Nucl. Instr. Methods 357, 391397.

Savoye, B., Cochonat, P., Apprioual, R., Bain, O., Baltzer, A., Bellec, V., Beuzart, P., Bourillet, J., Cagna, R., Cremer, M., Crusson, A., Dennielou, B., Diebler, D., Droz, L., Ennes, J., Floch, G., Foucher, J., Guiomar, M., Harmegnies, F., Kerbrat, R., Klein, B., Khun, H., Landure, J., Lasnier, C., Le Drezen, E., Le Formal, J., Lopez, M., Loubrieu, B., Marsset, T., Migeon, S., Normand, A., Nouze, H., Ondreas, H., Pelleau, P., Saget, P., Seranne, M., Sibuet, J.C., Tofani, R., Voisset, M., 2000. Structure et évolution récente de l'éventail turbiditique du Zaïre: Premier résultats scientifiques des missions d'exploration ZaiAngo 1 and 2 (Marge Congo-Angola). C. R.Acad. Sci. Paris 311, 211-220.

Schmidt, S., van Weering, T., Reyss, J.L., van Beek, P., 2002. Seasonal deposition and reworking at the sediment-water interface on the north western Iberian margin. Progr.Oceanogr. 52, 331-348.

Seiter, K., Hensen, C., Zabel, M., 2005. Benthic carbon mineralization on a global scale. Glob. Biogeochem. Cycles 19, 49-74.

Seylers, P., Coynel, A., Moreira-Turcq, P., Etcheber, H., Colas, C., Orange, D., Bricquet, J.P., Laraque, A., Guyot, J.L., Olivry, J.C., Meybeck, M., 2005. Organic carbon transported by the equatorial rivers: Example of Congo-Zaire and Amazon basins. In: E.J. Roose, R. Lal, C. Feller, B. Barthès, B.A. Stewart (Eds.), Soil Erosion and Carbon dynamics, Advances in Soil Science, CRC Press, Boca Raton, Florida, USA. pp. 255-274. 
Smith, K.L.J., 1987. Food energy supply and demand: A discrepency between particulate organic carbon flux and sediment community oxygen consumtion in the deep ocean. Limnol. Oceanogr. 32, 201-220.

Smith, K.L.J., Baldwin, R.J., Williams, P.M., 1992. Reconciling particulate organic carbon flux and sediment community oxygen consumption in the deep North Pacific. Nature 359, 313316.

Smith, K.L.J., Kaufmann, R.S., 1999. Long-term discrepency between food supply and demand in the deep eastern Pacific ocean. Science 284, 1174-1177.

Spitzy, A., Ittekkot, V., 1991. Dissolved and particulate organic matter in rivers. In: R.F.C. Mantoura, J-M. Martin and R. Wollast (Ed.), Ocean margin processes in global change, Dahlem Workshop Reports, J. Wiley and sons, Berlin. pp. 5-17.

Sweerts, J.-P., De Beer, D., 1989. Microelectrode measurements of nitrate gradients in the littoral and profundal sediments of a meso-eutrophic lake (lake Vechten, the Netherlands). App. Envir. Microb. 55, 754-757.

Tengberg, A., Hovdenes, J., Andersson, H.J., Brocandel, O., Diaz, R., Hebert, D., Arnerich, T., Huber, C., Körtzinger, A., Khripounoff, A., Rey, F., Rönning, C., Schimanski, J., Sommer, S., Stangelmayer, A., 2006. Evaluation of a lifetime-based optode to measure oxygen in aquatic systems. Limnol. Oceanogr.: Methods 4, 7-17.

Treignier, C., 2005. Apports en matière organique marine et terrigène sur la marge équatoriale ouest africaine : rôle joué par le canyon sous-marin du Zaïre: Approche par les biomarqueurs lipidiques. Thèse de Doctorat de l'Université Paris VI, 129 p.

Treignier, C., Derenne, S., Saliot, A., 2006. Terrestrial and marine n-alcohol inputs and degradation processes relating to a sudden turbidity current in the Zaire canyon. Org. Geochem. 37, 1170-1184.

Tsunogai, S., Iseki, K., Kusakabe, M., Saito, Y., 2003. Biogeochemical cycles in the East China Sea: MASFLEX program. Deep-Sea Res. II 50, 321-326.

Ullman, W.J., Aller, R.C., 1982. Diffusion coefficients in nearshore sediments. Limnol. Oceanog. 27, 552-556.

Vangriesheim, A., Khripounoff, A., Savoye, B., this volume. Recurrent turbiditic events observed along the Congo deep-sea channel. Deep-Sea Res.

Ver, L.M., Mackenzie, F.T., Lerman, A., 1999. Carbon cycle in the coastal zone: effects of global perturbations and change in the past three centuries. Chem. Geol. 159, 283-304.

Walsh, J.J., 1988. On the nature of continental shelves. Academic press, London, 520pp.

Wefer, G., Fischer, G., 1993. Seasonal patterns of vertical particle flux in equatorial and coastal upwelling areas of the eastern Atlantic. Deep-Sea Res. 40, 1613-1645.

Wenzhöfer, F., Glud, R.N., 2002. Benthic carbon mineralization in the Atlantic: A synthesis based on in situ data from the last decade. Deep-Sea Res. 49, 1255-1279.

Wetzel, A., 1993. The transfer of river load to deep-sea fans: a quantitative approach. Amer. Assoc. Petrol. Geol. Bull. 77, 1679-1692.

Wollast, R., 1993. Interactions of carbon and nitrogen cycles in the coastal zone. In: R. Wollast, F.T. Mackenzie, L. Chou (Eds.), Interactions of C, N, P and S biogeochemical cycles and global change, 4, NATO ASI series, Springer-Verlag, Berlin. pp. 195-210.

Wollast, R., 1998. Evaluation and comparison of the global carbon cycle in the coastal zone and in the open ocean. In: K.H. Brink, A.R. Robinson (Eds.), The Sea, Wiley \& sons, New York. pp. 213-252.

Wollast, R., Chou, L., 2001. Ocean Margin EXchange in the Northern Gulf of Biscay: OMEX I. An introduction. Deep-Sea Res. II 48, 2971-2978.

Tables

Table 1: Position and characteristics of the stations investigated during Biozaire cruises 


\begin{tabular}{|c|c|c|c|c|}
\hline Station & $\begin{array}{l}\text { Depth } \\
(\mathrm{m})\end{array}$ & Position & $\begin{array}{c}\text { Temperature } \\
\left({ }^{\circ} \mathrm{C}\right)\end{array}$ & $\begin{array}{l}\text { Oxygen } \\
(\mu \mathrm{mol} / \mathrm{l})\end{array}$ \\
\hline A & 1304 & $\mathrm{~S} 07^{\circ} 21 ; \mathrm{E} 11^{\circ} 30$ & 4.21 & 202 \\
\hline C & 3994 & $\mathrm{~S} 07^{\circ} 40 ; \mathrm{E} 10^{\circ} 00$ & 2.31 & 220 \\
\hline D & 3964 & $\mathrm{~S} 05^{\circ} 51 ; \mathrm{E} 08^{\circ} 21$ & 2.36 & 229 \\
\hline $\mathbf{R}$ & 3174 & $\mathrm{~S} 05^{\circ} 49 ; \mathrm{E} 09^{\circ} 43$ & 2.57 & 240 \\
\hline Tete & 334 & $\mathrm{~S} 06^{\circ} 00 ; \mathrm{E} 11^{\circ} 30$ & 15.02 & 79.1 \\
\hline Lobe & 4788 & $\mathrm{~S} 06^{\circ} 28 ; \mathrm{E} 06^{\circ} 02$ & 2.30 & 229 \\
\hline
\end{tabular}

Table 2: duration and interval of sampling of sediment traps. Each mooring except $\mathrm{R}$ contains a trap at 30 m.a.b. and a trap at 400 m.a.b. Mooring were positioned at the stations given in Table 1.

\begin{tabular}{cccc}
\hline Station & $\begin{array}{c}\text { Sampling duration } \\
\text { (year) }\end{array}$ & $\begin{array}{c}\text { Sample interval } \\
\text { (days) }\end{array}$ & Number of samples \\
\hline A & $2001-2002-2003$ & $10-15$ & 72 \\
C & $2000-2002-2003-2004$ & $10-15$ & 96 \\
D & $2000-2001-2002-2003-$ & $10-15$ & 120 \\
& 2004 & & 8 \\
R & $2 / 2003-5 / 2003$ & 12 & \\
\hline
\end{tabular}

Table 3: Annual fluxes of mass and organic carbon in $\mathrm{mg} \mathrm{m}^{-2} \mathrm{~d}^{-1}$ measured during four years in the Congo margin. 


\begin{tabular}{|c|c|c|c|c|c|c|c|}
\hline & & 2000 & 2001 & 2002 & 2003 & 2004 & Average \\
\hline Station A & Tot & - & 83.9 & 167.5 & 115 & - & 123.2 \\
\hline (400 m a.b.) & Org-C & & 6.8 & 12.6 & 8.1 & & 9.2 \\
\hline Station A & Tot & 447 & - & - & - & - & 447 \\
\hline (30 m a.b.) & Org-C & 22.1 & & & & & 22.1 \\
\hline Station C & Tot & 83.5 & - & 64. & 59.5 & 61.2 & 67.2 \\
\hline (400 m a.b.) & Org-C & 6.2 & & 4.2 & 3.5 & 4.2 & 4.5 \\
\hline Station C & Tot & 120.2 & - & - & - & - & 120.2 \\
\hline (30 $\mathrm{m}$ a.b.) & Org-C & 8.0 & & & & & 8.0 \\
\hline Station D & Tot & 97 & 84.8 & 80.4 & 80.4 & 68.3 & 80.7 \\
\hline (400 m a.b.) & Org-C & 5.6 & 5.5 & 4.6 & 3.9 & 3.9 & 4.7 \\
\hline Station D & Tot & 194.5 & 565.7 & - & 64. & 59.4 & 221.0 \\
\hline (30 $\mathrm{m}$ a.b.) & Org-C & 10.3 & 25.3 & & 1.3 & 3.3 & 10.0 \\
\hline Station R & Tot & - & - & - & - & 141.3 & 141.3 \\
\hline (400 m a.b.) & Org-C & & & & & 7.3 & 7.3 \\
\hline
\end{tabular}


Table 4: Diffusive and total oxygen uptake (DOU and TOU respectively) measured in situ by microprofiling and benthic chamber and on board by microprofiling (number of profiles or chambers between brackets). The ratio of TOU/DOU for in situ measurements performed in 2003 is also included.

\begin{tabular}{|c|c|c|c|c|c|c|}
\hline Station & $\begin{array}{l}\text { Depth } \\
(\mathrm{m})\end{array}$ & $\begin{array}{c}\text { In situ DOU } \\
2003 \text { (Biozaire } \\
3) \\
\left(\mathrm{mmol} \mathrm{m}^{-2} \mathrm{~d}^{-1}\right)\end{array}$ & $\begin{array}{c}\text { On board DOU } \\
2003 \text { (Biozaire } \\
3) \\
\left(\mathrm{mmol} \mathrm{m}^{-2} \mathrm{~d}^{-1}\right)\end{array}$ & $\begin{array}{c}\text { In situ TOU } \\
2001 \text { (Biozaire } \\
2) \\
\left(\mathrm{mmol} \mathrm{m}^{-2} \mathrm{~d}^{-1}\right)\end{array}$ & $\begin{array}{c}\text { In situ TOU } \\
2003 \text { (Biozaire } \\
3) \\
\left(\mathrm{mmol} \mathrm{m}^{-2} \mathrm{~d}^{-1}\right)\end{array}$ & TOU/DOU \\
\hline$A$ & 1302 & $2.8 \pm 1.1$ & $3.1 \pm 0.6$ & $3.2 \pm 0.5$ & $4.0 \pm 0.6$ & $1.4 \pm 0.8$ \\
\hline C & 4001 & $0.8 \pm 0.3$ & $3.3 \pm 0.4$ & $1.6 \pm 0.3$ & $2.4 \pm 0.2$ & $3.0 \pm 1.5$ \\
\hline $\mathrm{D}$ & 3962 & $1.2 \pm 0.1$ & $1.9 \pm 0.5$ & $2.0 \pm 0.3$ & $1.9 \pm 0.3$ & $1.6 \pm 0.4$ \\
\hline $\mathrm{R}$ & 3154 & $2.3 \pm 0.8$ & $2.3 \pm 0.5$ & & $3.6 \pm 0.5$ & $1.5 \pm 0.7$ \\
\hline Tete & 334 & & $1.50 \pm 0.05$ & & & \\
\hline Lobe & 4788 & & $19.8 \pm 1.8$ & & & \\
\hline
\end{tabular}


Table 5 : Mass balance for Org-C at 4 stations near the Congo channel and the Angola margin. All terms in mol m $\mathrm{m}^{-2} \mathrm{y}^{-1}$ except ratio unsupported/vertical flux. See text for details on calculation of each term.

\begin{tabular}{cccccc}
\hline Station & $\begin{array}{c}\text { POC flux } \\
(400 \mathrm{~m}) \\
\left(\mathrm{mol} \mathrm{m}^{-2} \mathrm{y}^{-1}\right)\end{array}$ & $\begin{array}{c}\text { Org-C } \\
\text { Mineralization } \\
\left(\mathrm{mol} \mathrm{m}^{-2} \mathrm{y}^{-1}\right)\end{array}$ & $\begin{array}{c}\text { Org-C } \\
\text { Burial } \\
\left(\mathrm{mol} \mathrm{m}^{-2} \mathrm{y}^{-1}\right)\end{array}$ & $\begin{array}{c}\text { Unsupported POC } \\
\text { flux }\left(\mathrm{mol} \mathrm{m}^{-2} \mathrm{y}^{-1}\right)\end{array}$ & $\begin{array}{c}\text { Unsupported } \\
\text { Nertical flux }\end{array}$ \\
\hline A & 0.28 & 1.10 & 0.62 & 1.44 & 5.1 \\
C & 0.14 & 0.61 & 0.30 & 0.77 & 5.6 \\
D & 0.14 & 0.59 & 0.56 & 1.01 & 7.1 \\
R & 0.22 & 1.10 & 1.08 & 1.96 & 8.8 \\
\hline
\end{tabular}

\section{Figures}

Fig.1: bathymetric map of the Congo Canyon and channel with the stations investigated during the Biozaire cruises (2001 and 2003). Stations 1702 and 4913 refer to the paper by Wenzhöfer and Glud (2002).

Fig. 2: A schematic view of the RAP 2 platform with the benthic chamber and the microprofiler on the same Lander. 1: Radio beacon and flasher. 2: Acoustic releases. 3: Argos beacon. 4: Floatation. 5: Mechanical release. 6: Ballast. 7: Video camera. 8: Energy for camera. 9: Benthic chamber. 10: Lid closing. 11: Stirring. 12: Water sampler. 13: Main pushing mechanism. 14: Energy and electronic housings. 15: Main platform. 16: Parachute housing. 17: Profiler

Fig. 3: Distribution with depth of porosity, organic carbon, total nitrogen, inorganic carbon and $\mathrm{C} / \mathrm{N}$ ratio in the sediments from the Congo area. Station $A, C, D, R$, Tete and Lobe.

Fig. 4: Microporosity (triangles) and inverse formation factor (dashed line) for the three stations $A, C$ and $D$. Thin solid lines represent best fit using $m=3$ and thick solid lines are $\mathrm{m}=4$ or 4.5 (see text).

Fig. 5: Sediment trap fluxes measured over a period of 3-4 years in the Congo area. Mass fluxes and organic carbon fluxes are plotted separately. Biozaire 2 expedition occurred during December 2001 and Biozaire 3 in December 2003-January 2004. Most benthic chamber and microprofiler measurements were made during Biozaire 3.

Fig. 6: Elemental composition of particles (a) and superficial sediment (b) for stations A, C and $D$

Fig. 7: Oxygen profiles measured on the Congo margin sediments. Symbols represent in situ measured profiles using the Profilo on RAP2, full lines represent on board measurements performed on sediment cores from the multicorer. For the Lobe station, the inner graph represents a zoom of the first $2 \mathrm{~mm}$ below the sediment-water interface.

Fig. 8: Chemical analysis and optode records during the RAP2 incubations at our different stations (square: chemical analysis; curve: optode record) 
Fig. 9: Oxygen demand measured in situ. White bars are the total oxygen uptake (TOU) measured by the benthic chambers while the black bars are diffusive oxygen uptake (DOU) calculated from the oxygen microprofiles using the profile software.

Fig. 10: Short live radionuclides measured in sediments from the Congo margins, with sedimentation rates from ${ }^{210} \mathrm{~Pb}_{\mathrm{xs}}\left(\mathrm{mm} \mathrm{yr}^{-1}\right)$.

Fig. 11: Comparison of Biozaire in situ values with other oxygen uptake measurement from this margin and regressions from different eastern and western margins. Western Altlantic and eastern Pacific regressions were made on TOU, whereas Eastern Atlantic regression was achieved on DOU. The white triangles represent total oxygen uptakes from the Congo Canyon and Angola/Guinea margins compiled by (Wenzhöfer and Glud, 2002) whereas the black symbols are this study. The large grey squares correspond to onboard measurements performed on station Tete and Lobe. Note that the scale is broken for Lobe, the number in brackets is the oxygen flux calculated from the profiles. 


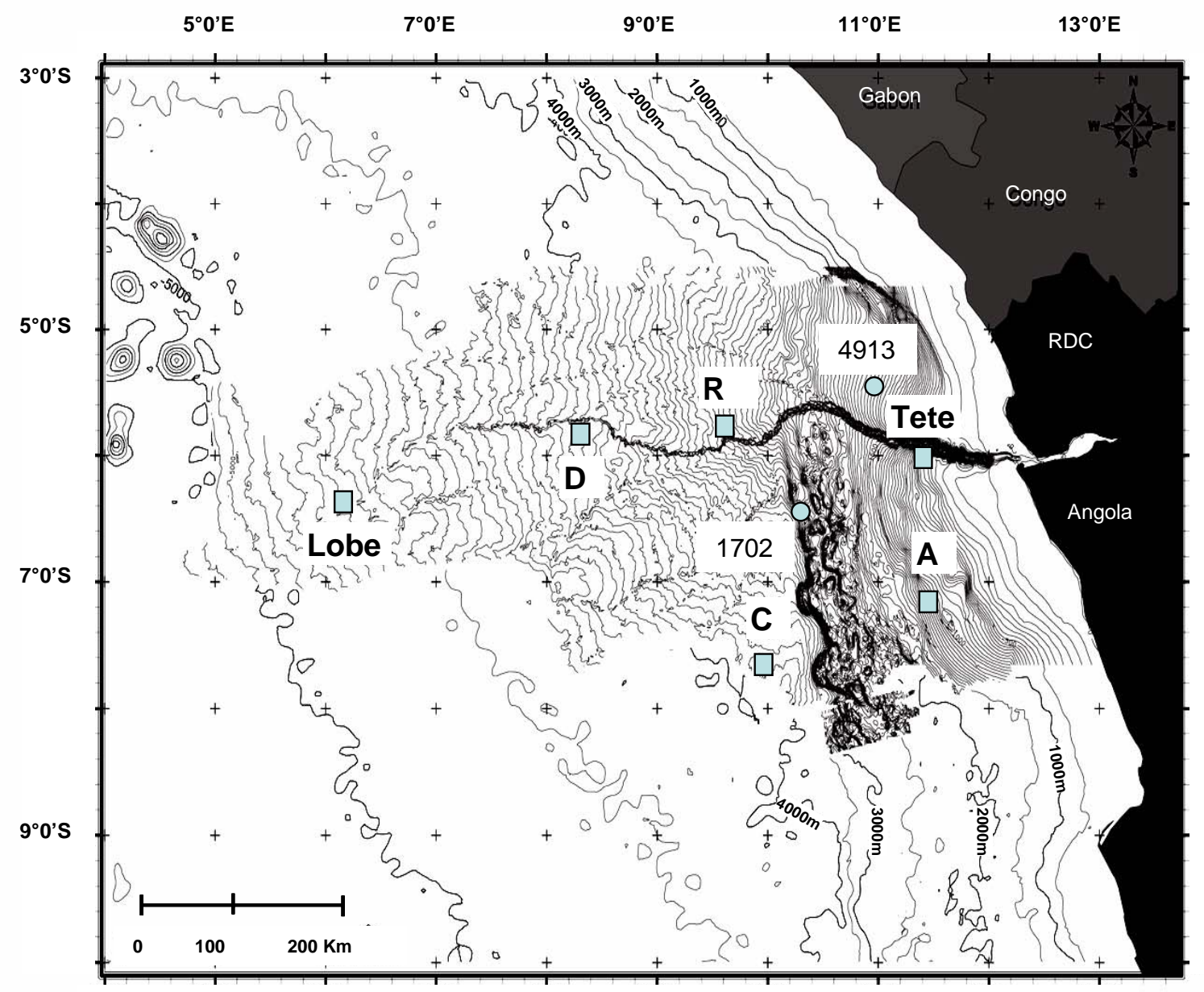

Figure 1 (Rabouille et al.) 


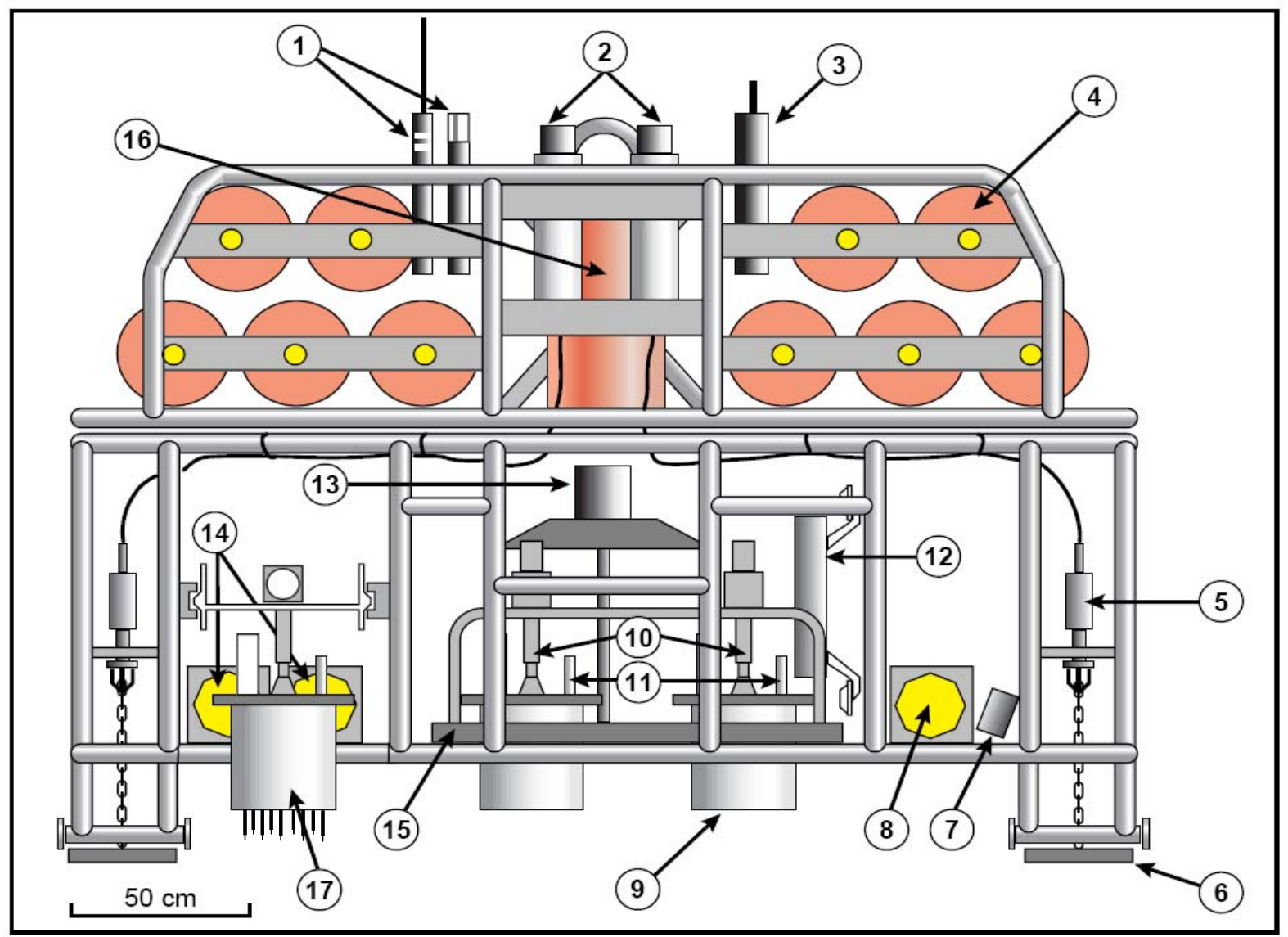

Figure 2 (Rabouille et al.) 
Porosity Organic C. Nitrogen Inorganic C. Org C./N

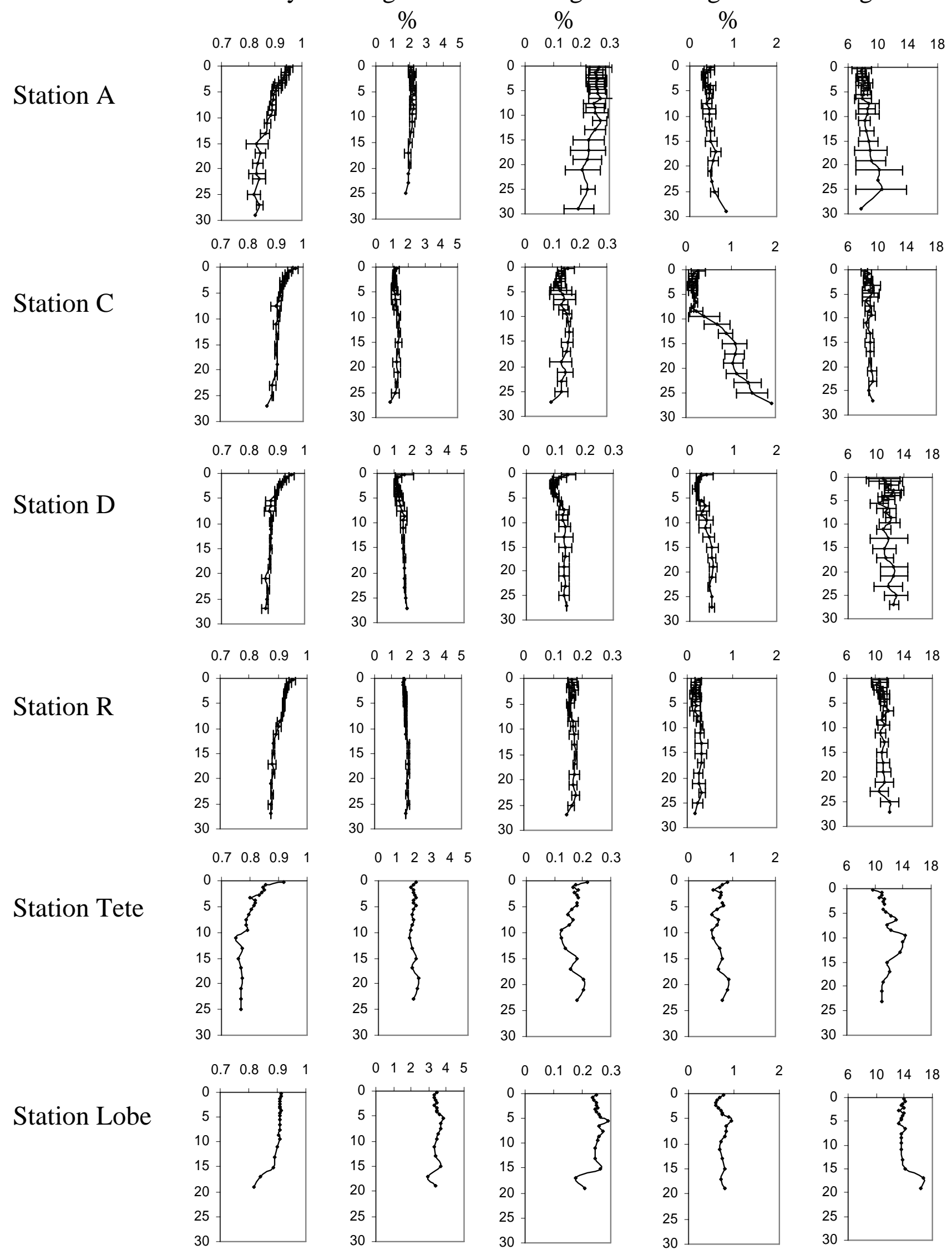

Figure 3 (Rabouille et al.) 

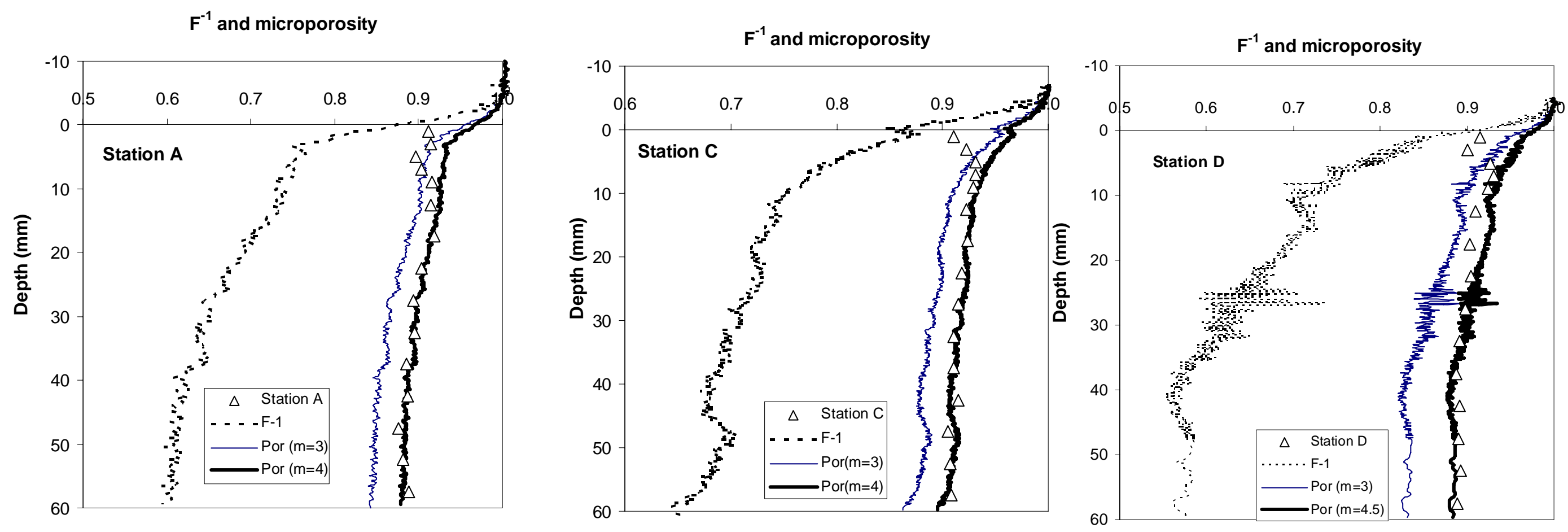

Figure 4 (Rabouille et al.) 



Figure 5 (Rabouille et al.) 

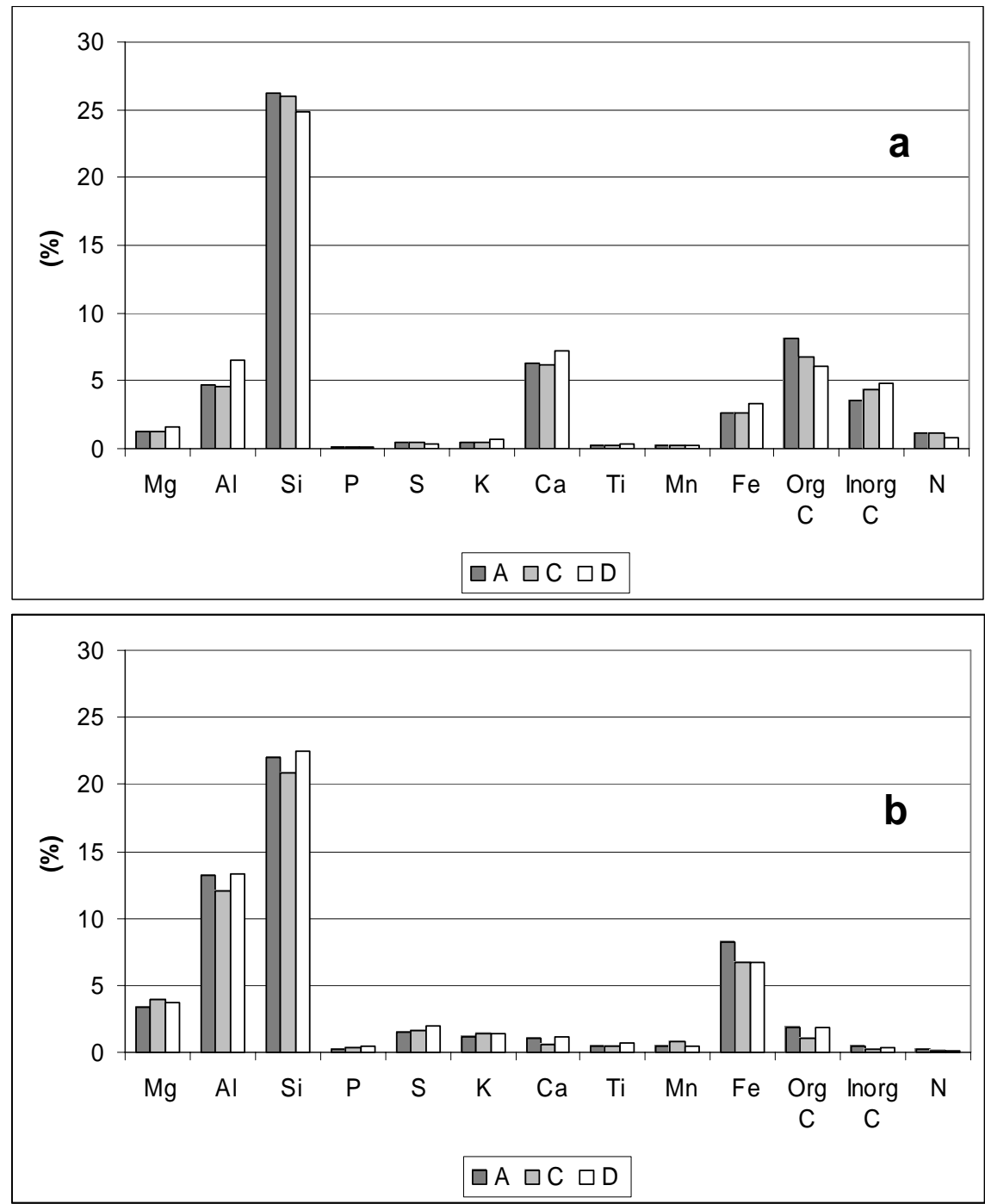

Figure 6 (Rabouille et al.) 

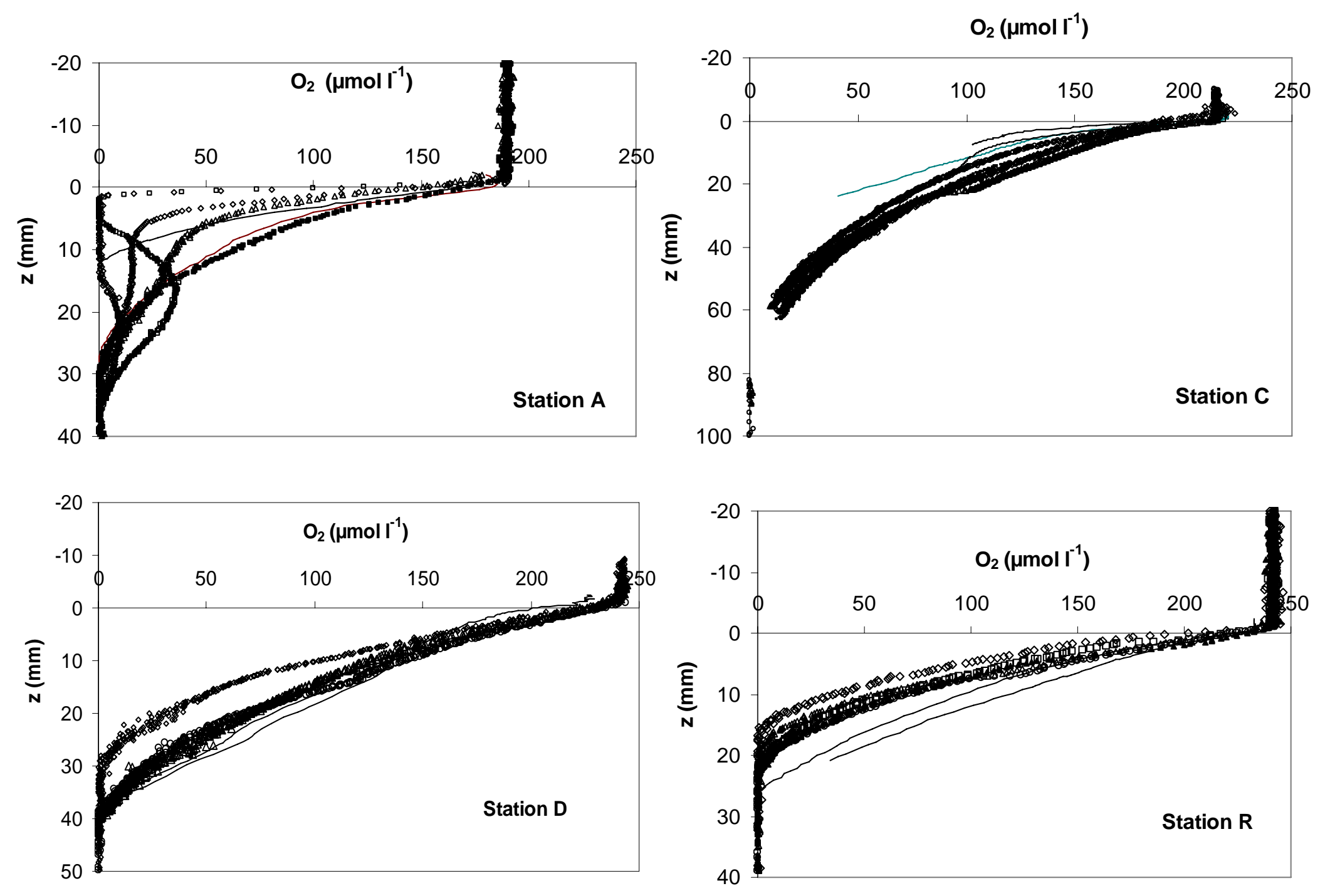

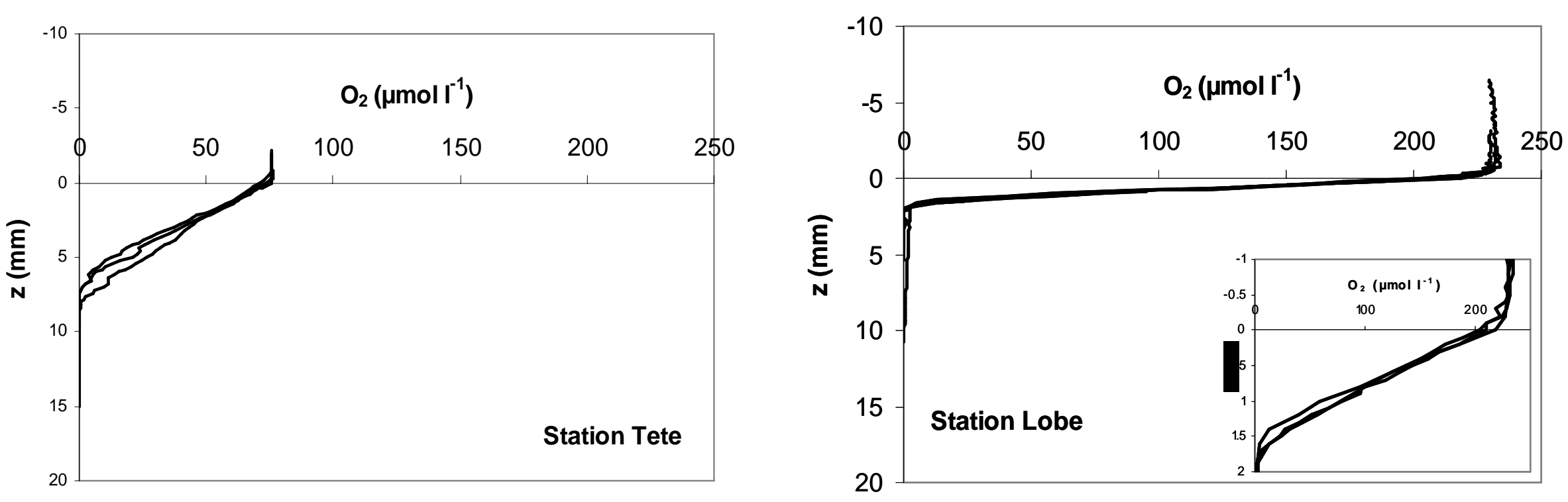

Figure 7 (Rabouille et al.) 

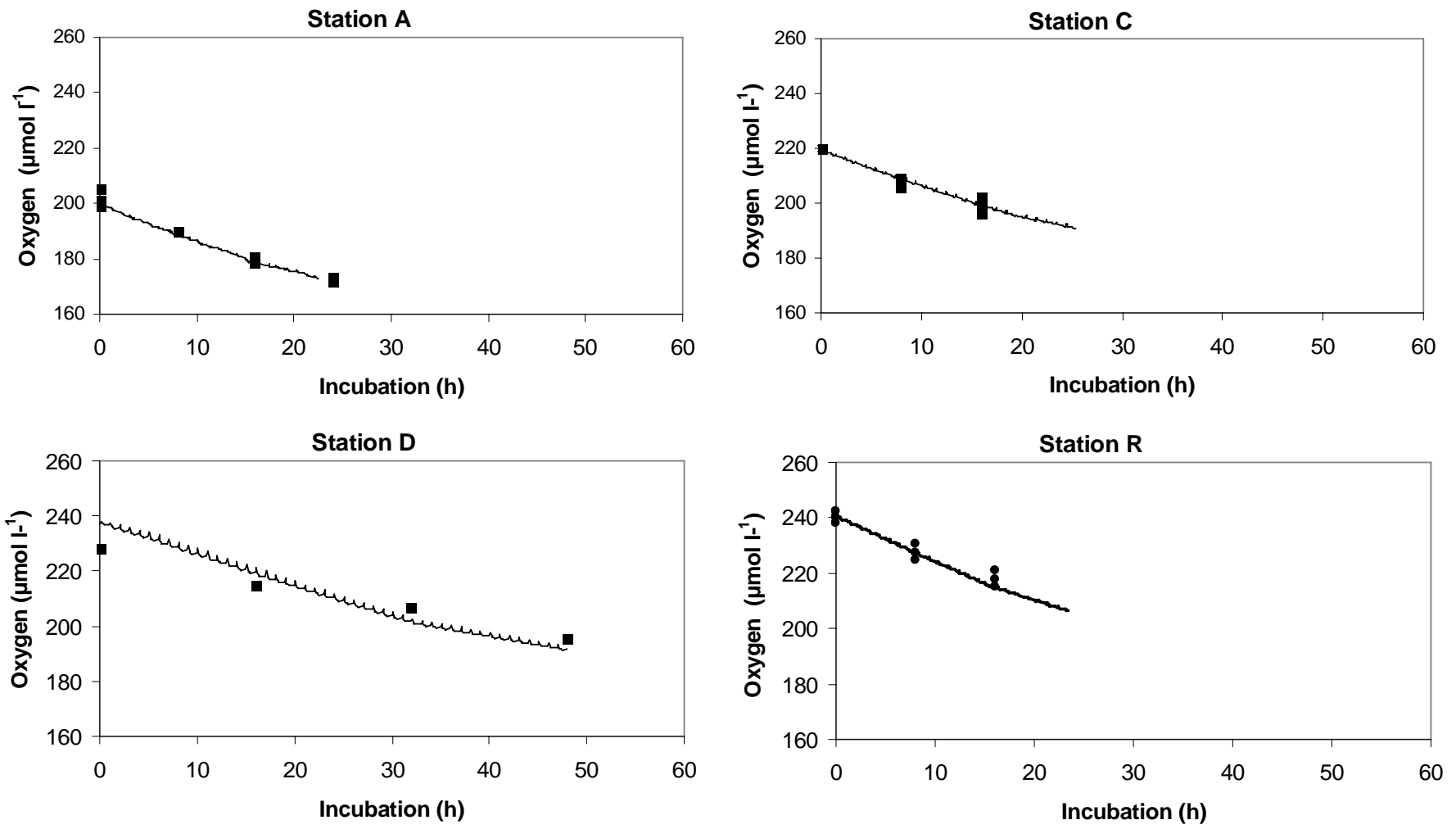

Figure 8 (Rabouille et al.) 


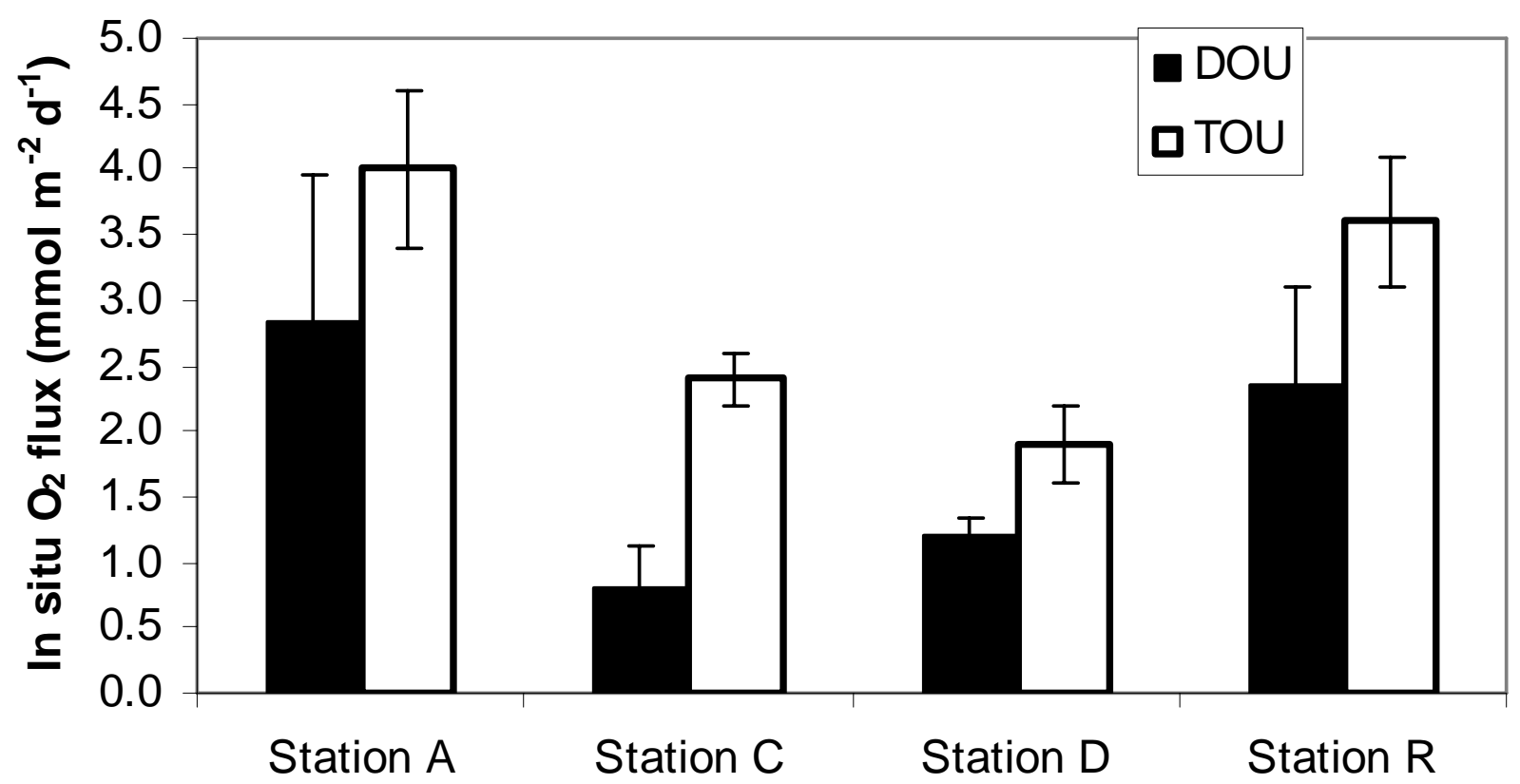

Figure 9 (Rabouille et al.) 


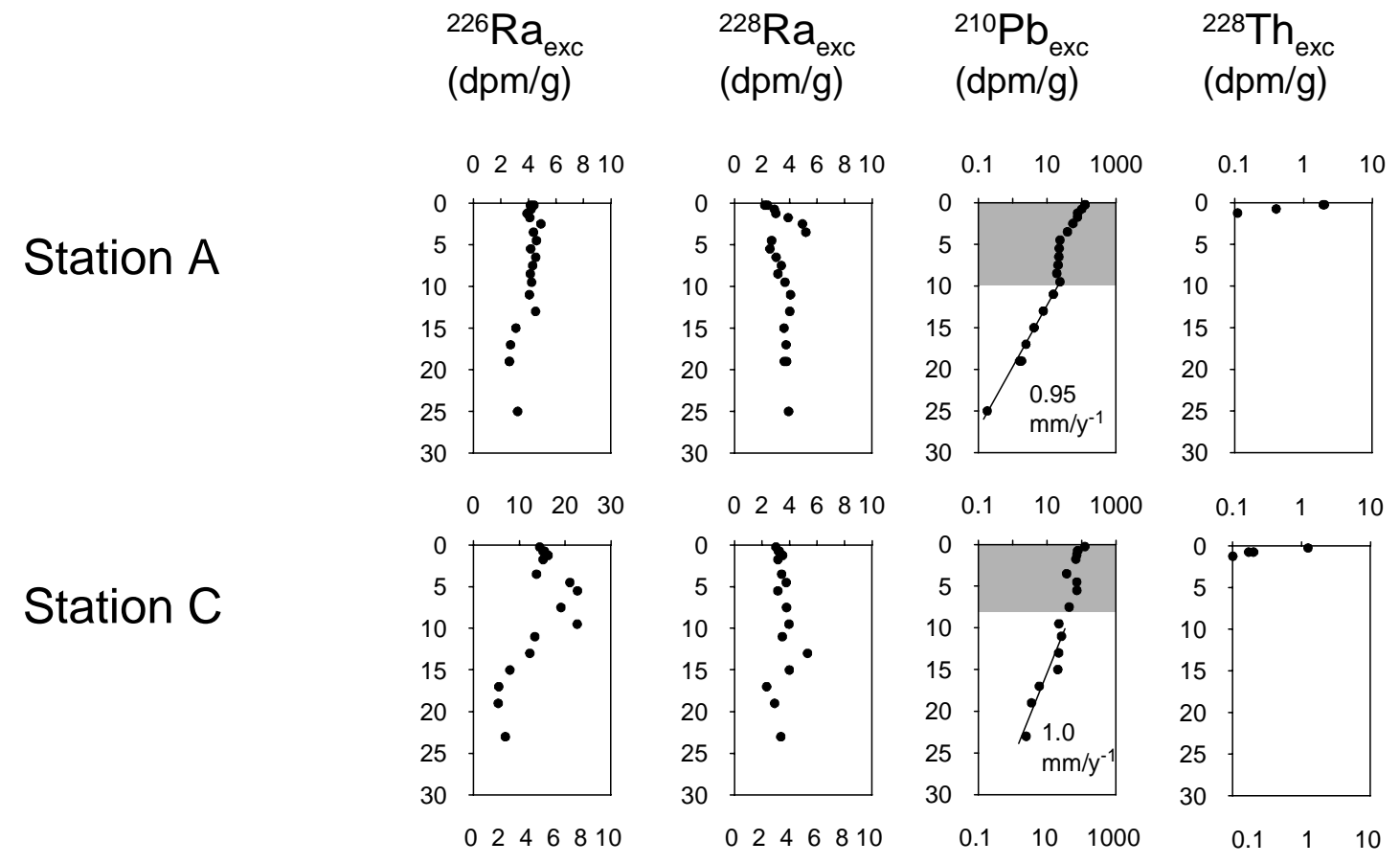

Station D
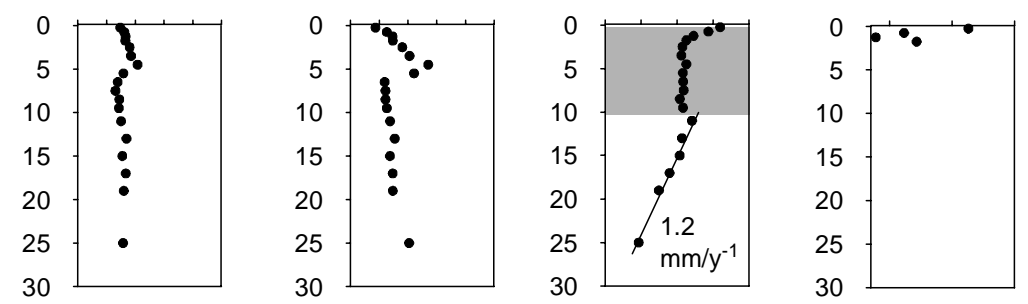

Station R
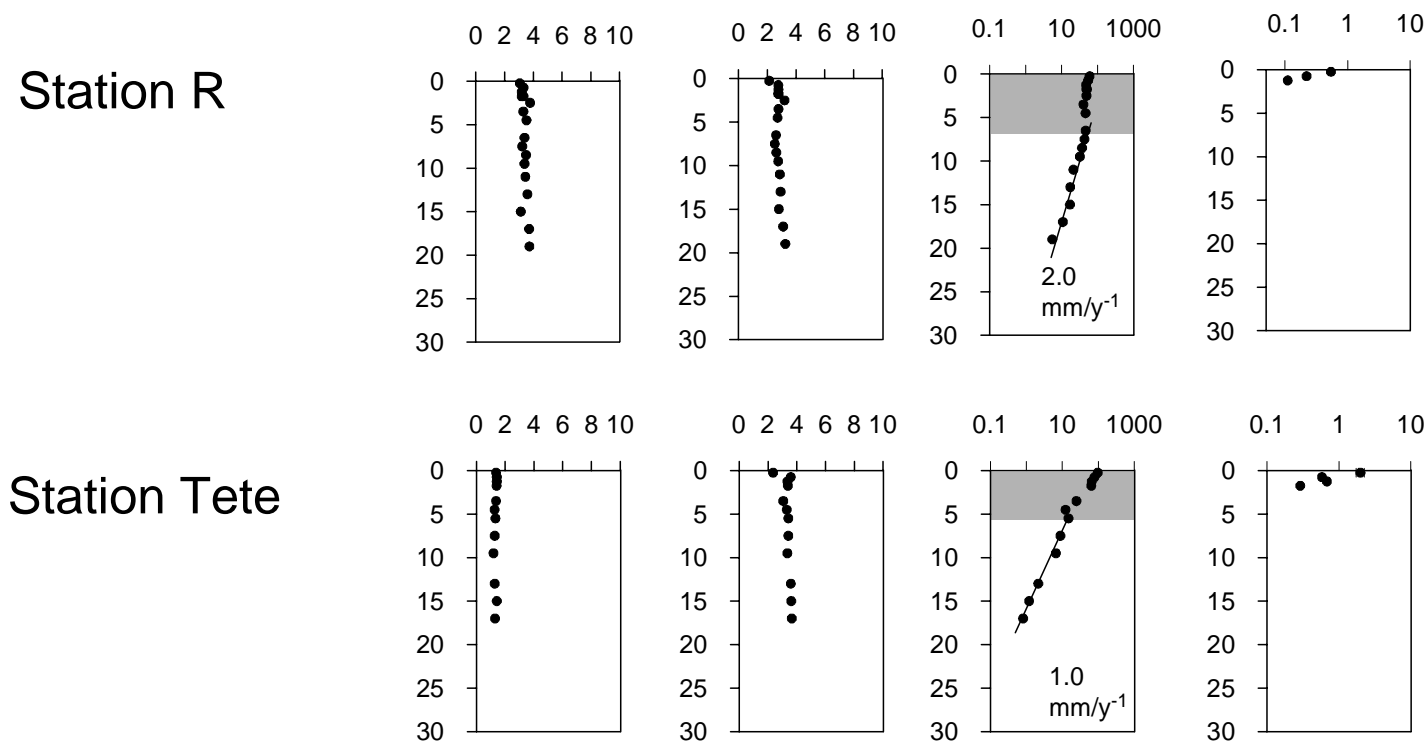

0246810
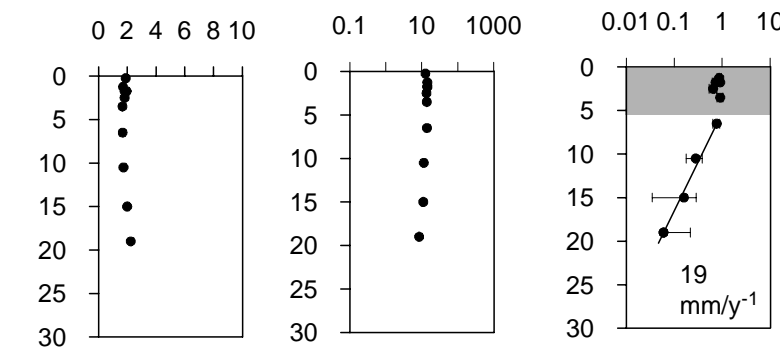

Figure 10 (Rabouille et al.).

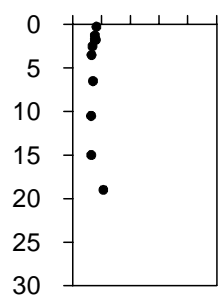




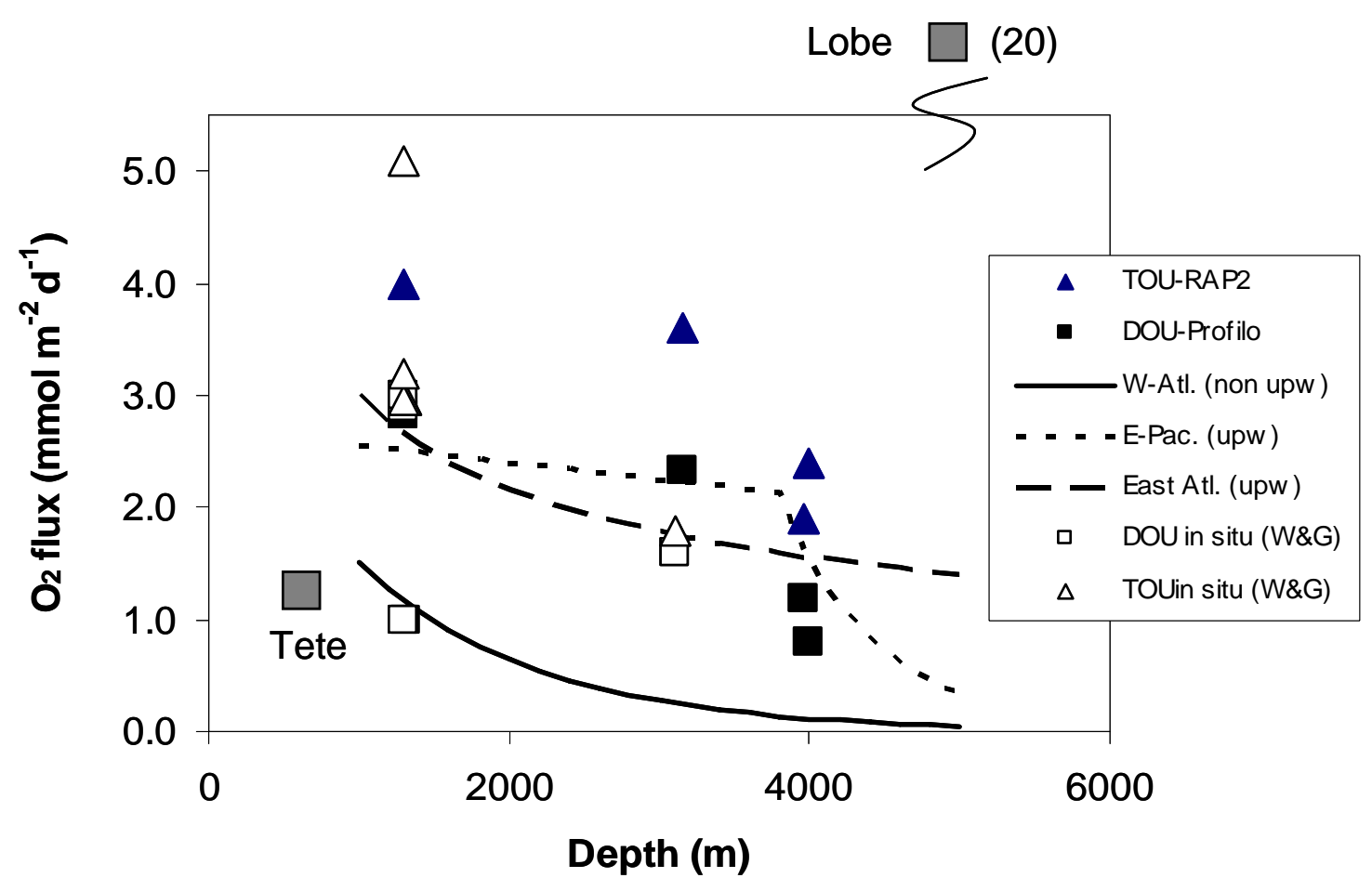

Figure 11 (Rabouille et al.) 